\title{
The role of allopatric speciation and ancient origins of Bathynellidae (Crustacea) in the Pilbara (Western Australia): two new genera from the De Grey River catchment
}

\section{Giulia Perina}

Centre for Ecosystem Management, School of Science, Edith Cowan University, 270 Joondalup Dv, Joondalup, WA 6027, Australia

Western Australian Museum, Locked Bag 49, Welshpool DC, Western Australia 6986, Australia g.perina@ecu.edu.au

\section{Ana I. Camacho}

Museo Nacional de Ciencias Naturales (CSIC), Dpto. Biodiversidad y Biología Evolutiva C/ José Gutiérrez Abascal 2, 280o6-Madrid, Spain

\section{Joel Huey}

Centre for Ecosystem Management, School of Science, Edith Cowan University, 270 Joondalup Dv, Joondalup, WA 6027, Australia

Western Australian Museum, Locked Bag 49, Welshpool DC, Western Australia 6986, Australia The University of Western Australia, 35 Stirling Hwy, Crawley WA 6oog, Australia

\section{Pierre Horwitz}

Centre for Ecosystem Management, School of Science, Edith Cowan University, 270 Joondalup Dv, Joondalup, WA 6027, Australia

\section{Annette Koenders}

Centre for Ecosystem Management, School of Science, Edith Cowan University, 270 Joondalup Dv, Joondalup, WA 6o27, Australia

\begin{abstract}
The stygofaunal family of Bathynellidae, is an excellent group to study the processes that shape diversity and distribution, since they have unknown surface or marine relatives, high level of endemism, and limited dispersal abilities. Recent research on Bathynellidae in Western Australia (Pilbara) has uncovered new taxa with unexpected distributions and phylogenetic relationships, but the biogeographical processes that drive their diversification on the continent are still unclear. By exploring the diversity, distribution, and
\end{abstract}


divergence time of Bathynellidae in a setting such as the perched and isolated aquifers of the Cleaverville Formation in the north of the De Grey River catchment (Pilbara), we aim to test the hypothesis that vicariance has shaped the distribution of this family, specifically if one or multiple vicariant events were involved. We analysed the specimens collected from perched water in different plateaus of the Cleaverville Formation, combining morphological and molecular data from mitochondrial and nuclear genes. We described two new species and genera (Anguillanella callawaensis gen. et sp. nov. and Muccanella cundalinensis gen. et sp. nov.), and two additional taxa are recognised using morphology and/or Automatic Barcode Gap Discovery and Poisson Tree Processes species delimitation methods. New genera and species result restricted to isolate perched aquifers on single plateaus and their distributions, phylogenetic relationships, and divergence time estimates support multiple vicariant events and ancient allopatric speciation.

\section{Keywords}

ABGD - Anguillanella gen. nov - Bathynellidae - new species - Muccanella gen. nov - PTP stygofauna

\section{Introduction}

Subterranean species distributions are often restricted, and confined to particular geologies, for example isolated karst systems, limestone, fractured banded iron formations (BIFs), and porous hyporheic systems (Culver \& Pipan, 2008; Harvey, 2002; Humphreys, 2017; Trontelj et al., 2009). For this reason many subterranean taxa are considered short-range endemics (SREs; sensu Harvey, 2002). Their small geographic ranges, and high rate of endemism make them ideal candidates to explore historical climatic and geological events. For example ice sheet coverage during the Quaternary glaciations influenced the distribution of the subterranean amphipod species of Stygobromus in north America (Holsinger etal., 1997) and Niphargusvireiin France(Foulquier etal., 2008). The occurrence of the cirolanid isopod Antrolana lira in areas formerly submerged by the ocean, confirms the role of marine transgression in shaping cirolanid distributions (Holsinger et al., 1994), and the presence of troglobitic salamanders in Texan caves suggests the ancestor of this radiation migrated underground to survive climate aridification(Sweet, 1982).
Aquatic subterranean animals (stygobionts) often have larger distributions than terrestrial subterranean animals (troglobionts) (Barr \& Holsinger, 1985; Christman \& Culver, 2001; Lamoreaux, 2004). This can be due to a larger suitable continuous environment, such as the presence of groundwater in different but adjacent geological layers, or to flooding events that would increase the opportunity for dispersal (Lamoreaux, 2004). Small stygobionts are collected not only from karst areas, but also from saturated interstices in alluvial/colluvial deposits (Barr \& Holsinger, 1985; Holsinger, 1988; Marmonier et al., 1993; Christman \& Culver, 2001). In other cases, distributions of stygofaunal species can be restricted to small areas (Eberhard et al., 2009). Geographically close aquifers can be isolated by impermeable or semi-impermeable material such as clay, mudstone or other deposits with very low hydraulic conductivity. Accordingly, adjacent groundwater bodies can harbour different stygofaunal species. For example, calcrete aquifers in ancient palaeochannels of the Yilgarn region, in the arid zone of Western Australia, are considered "islands under the desert" and host different Downloaded from Brill. come4/26/2023 12:35:40pM via free access 
stygofauna communities (Cooper et al., 2002, 2008; Guzik et al., 2008; Humphreys et al., 2009; Karanovic \& Cooper, 2011).

To be recognised as perched, aquifers are located above the regional water table, in the vadose zone (the unsaturated zone below the land surface). This occurs when there are layers of rocks or sediments with very low permeability such as clay, granite or mudstone, above the main water table but below the land surface (Fitts, 2012). Perched aquifers commonly form in arid, semi-arid climates (Sedghi, 2016), and can be occasionally connected to local aquifer systems, particularly during rain seasons and flooding events (Johnson \& Wright, 2001). Perched aquifers within the same area in arid regions (isolated or partially isolated from regional groundwater), were probably historically connected during groundwater table fluctuations, and/or marine transgressions. For example, perched aquifers in the arid zones of Western Australia were interconnected during wetter periods when large river systems were flowing and water table was higher (Van de Graaff et al., 1977; BMR Palaeogeographic Group, 1990; González-Álvarez et al., 2016).

The Pilbara region, in the arid zone of Western Australia, exhibits many different types of aquifers, sometimes with complex hydrological connectivity. Groundwater can be contained in unconsolidated sedimentary aquifers (alluvium and colluvium in Cainozoic valley fills), chemically deposited aquifers (mainly formed by calcrete and limonite within alluvium and colluvium formations), and fractured rock aquifers, comprising Precambrian basement rock (like BIFs, dolomite and sandstone) and distinct types of aquifers can occur in the same area (Johnson \& Wright, 2001). Perched aquifers are also present in the region in various geologies (Hickman et al., 1983; Johnson \& Wright, 2001; WorleyParsons, 2012; Department of Water, 2016). Aquifers are recharged by rainfall and surface water, are generally fresh to brackish (Department of Water, 2010) and host a highly diverse stygofauna. Halse (2018) estimates 1329 stygofaunal species for the Pilbara alone, whose distributions reflect in part the hydrogeological complexity of the region (Finston et al., 2009, 2007; Brown et al., 2015; Perina et al., 2019).

Bathynellidae are a common component of stygofauna in different aquifers of the Pilbara region, including perched aquifers. They represent an ideal taxon to test biogeographic hypotheses as they are confined to the interstitial and subterranean environment, have no known epigean or marine relatives, and have limited dispersal abilities (Schminke, 1974; Humphreys, 2008; Coineau \& Camacho, 2013). The impediments of conservative morphology and poorly resolved taxonomy, often leading to inaccurate species identifications (Camacho et al., 2018), have been alleviated in recent years, by molecular tools which have been used to integrate morphological species studies and resolve phylogenetic relationships among taxa (Camacho et al., 2002; Camacho et al., 2013a, b). Understanding of the Australian bathynellids is still limited, but a recent study from one of the major catchments in the Pilbara, the Fortescue, revealed distantly related taxa within the same catchment and even within the same aquifer (Perina et al., 2018, 2019), suggesting a complex and ancient biogeographical history. Similar results have been obtained in a study of bathynellids in south Queensland (Little et al., 2016). All investigations conducted so far in Australia, though, do not clarify the biogeographical processes that can drive Bathynellidae diversification on the continent.

In this study we aim to test vicariance in a setting that is apparently ideal; the perched aquifers of the Cleaverville formation in the north of the De Grey River in the Pilbara (fig. 1). This formation comprises ridges formed by Precambrian Banded Iron Formations (BIFs) containing perched water 


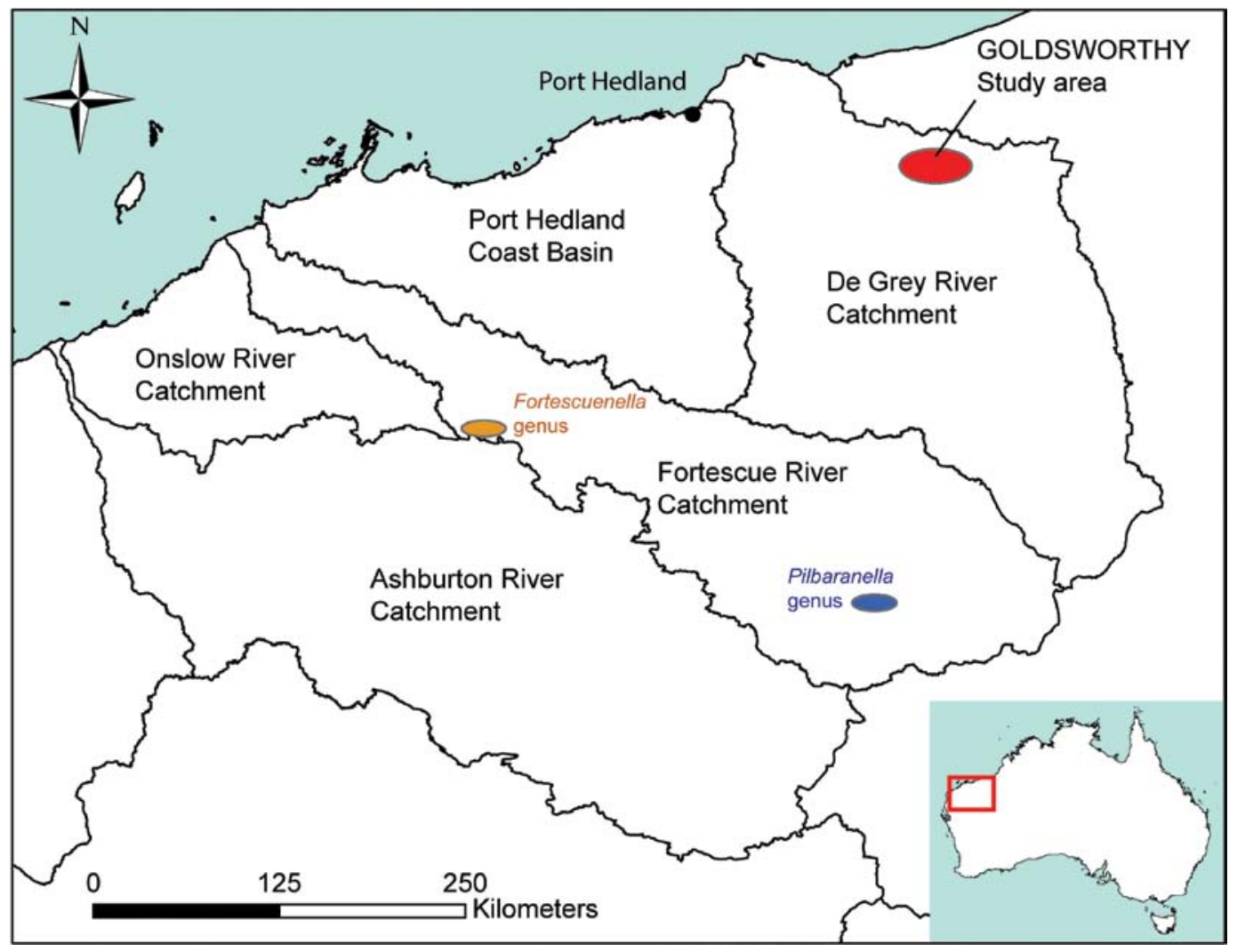

FIGURE 1 The Pilbara bioregion with the five major catchments. In red the Goldsworthy study area in the De Grey River catchment, east of Port Hedland town.

partially isolated from the regional alluvial aquifer (Hickman et al., 1983; Dames \& Moore, 1992). In the past these perched aquifers were interconnected by higher water table during the Upper Cretaceous/Early Tertiary (Van de Graaff et al., 1977; BMR Palaeogeographic Group, 1990; González-Álvarez et al., 2016), and by marine transgressions which occurred in different ages (Artinksian, Oxfordian, Aptian) (Hickman et al., 1983), when dispersal between aquifers, or the origin of a marine ancestor into the system, may have been facilitated. By exploring patterns of diversity (through morphological and molecular tools), species distribution, and divergence time of Bathynellidae in the north of the De Grey
River catchment, we aim to test two hypotheses. 1) a single vicariant event (for example a marine regression) isolated the perched aquifers at the same time, and therefore stygofauna, in different ridges and allopatric speciation occurred. The phylogeny expected would then show short internodes amongst the taxa identified, and low node support. 2) several vicariant events (geological events such as valley erosion and water level fluctuations) fragmented the ancestral population gradually in different ridges at different times. We would then expect multiple ancestors (nodes) at different times, with bathynellids occurring on the ridge separated by a deeper valley genetically more distinct from the others. 


\section{Material and methods}

\section{Study area and groundwater sampling methods}

The study area (the former Goldsworthy mining area) is located $170 \mathrm{~km}$ East of Port Hedland, in the north of the De Grey River catchment (fig. 1), one of the main catchments of the Pilbara bioregion, in the arid zones of WA. It comprises low hills, plateaus alternate with sandy plains and sporadic claypans. Different ridges of about $260 \mathrm{~m}$ Australian Height Datum are part of the Cleaverville Iron Formation (such as Callawa, Cundaline and Yarrie ridges), fractured and weathered Archeanaged formation (Hickman et al.,1983; Williams, 2003). Small and large gaps (for example Shay and Kimberley Gap) between the ridges allow the passage of many ephemeral creeks that run through the area (Dames \& Moore, 1992). Aquifers occur in the alluvial deposits, mainly in the De Grey River and Eel Creek, and in the Archean bedrock that forms the ridges in the area. There is evidence of a perched aquifer on Yarrie Ridge confined by granite and mudstone layers that underlie the BIF (see figure 3.2 in Dames \& Moore, 1992). Rainfall recharges the perched aquifer through infiltration of the permeable BIF on the plateau, but the low hydraulic conductivity of the beneath layers makes the discharge into the regional water in the alluvial of the De Grey and Eel Creek very slow (Dames \& Moore, 1992; Williams, 2003). All ridges of the Cleaverville Formation abut granitic rocks (Hickman et al., 1983) therefore groundwater contained in the BIF is partially isolated from the regional groundwater. In geological time frames, water tables have fluctuated much more than today, interconnecting the perched aquifers, with wetter periods of higher water levels, for example in the Cretaceous-Early Tertiary (BMR Palaeogeographic Group, 1990; González-Álvarez et al., 2016), and other periods where most of the area was submerged by marine transgressions, for example in the Artinksian, Oxfordian, and Aptian (Hickman et al., 1983). Connection and isolation of the perched aquifers probably occurred at different times, but with aridification processes started in the MidMiocene in the north of Western Australia (Van de Graaff et al., 1977; Macphail \& Stone, 2004; Byrne et al., 2008), water tables have dropped steadily, isolating the aquifers in the area.

In 2009 BHP Billiton proposed to mine Callawa and Cundaline ridges, therefore subterranean fauna surveys were carried out to contribute to the development of advice and recommendations to the Minister of the Environment on the proposal (Environmental Protection Authority, 2007, 2009). A preliminary molecular analysis conducted on Bathynellidae identified two lineages from Cundaline and Yarrie ridges respectively (Helix Molecular Solution, 2009), but specimens from Callawa ridge were not included in the analysis, therefore uncertainties on how many taxa are present in the area, and their relationships were unresolved (Subterranean Ecology, unpubl. data).

Given the presence of Bathynellidae in different ridges of the Cleaverville Iron Formation, the water table fluctuations over geological time, the drought climate established by the Pliocene (Macphail \& Stone, 2004) and the perched aquifers subsequently partially isolated from one another and from regional groundwater, we believe that this Goldsworthy area is an ideal setting to test for allopatric speciation in stygofauna.

The bathynellids collected in the Goldsworthy area during surveys between 2007 and 2009 by Subterranean Ecology is the source of the material used for this study. Stygofauna was sampled according to the EPA guidelines (Environmental Protection Authority, 2003, 2007), while specimen preservation follows Perina et al. (2018). 


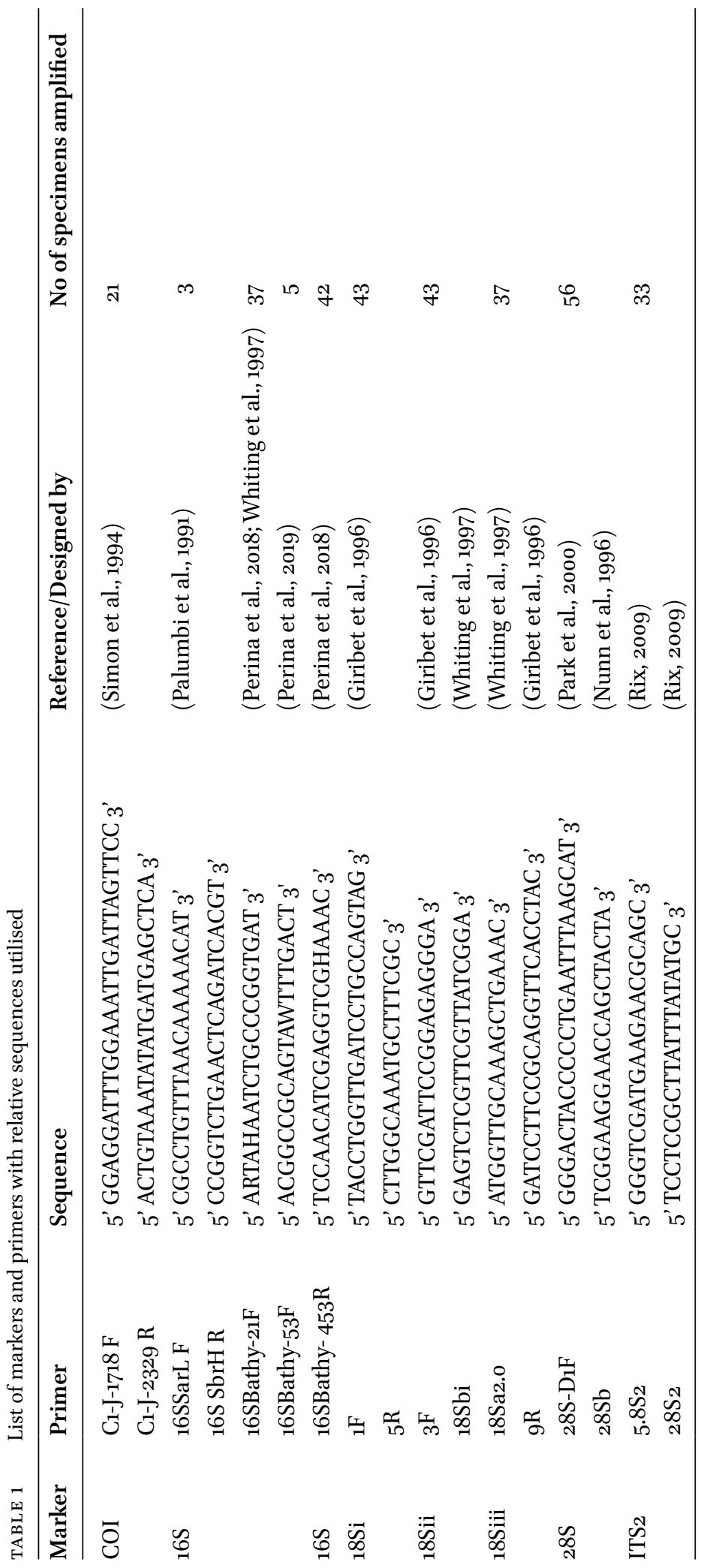




\section{DNA methods and data analysis}

Tissue sampling, DNA extraction, PCR amplification, and DNA sequencing follow the procedures described in Perina et al. (2018). The mitochondrial Cytochrome oxidase I (COI), and $16 \mathrm{~S}$ ribosomal RNA (16S), and the nuclear $28 \mathrm{~S}, 18 \mathrm{~S}$ ribosomal RNA, and the Internal Transcribed Spacer 2 (ITS2) markers were amplified using the primers listed in table 1.

We used LIMS (Laboratory Information Management Software) Biocode plug-in (http://www.mooreabiocode.org) to manage the molecular laboratory workflows. We imported the raw chromatograms into Geneious 10.2.4 software (Kearse et al., 2012), and assembled forward and reverse sequences. Each sequence was examined by eye and edited. The consensus sequences were generated and blasted against GenBank, and sequences representing contaminations were discarded from the analyses. The MAFFT (Multiple Alignment using Fast Fourier Transform) algorithm (Katoh et al., 2002) with default parameters was used to build the alignments. We used the online server GBlocks Version 0.91b (Castresana, 2000) to exclude poorly aligned sections of the $16 \mathrm{~S}$, ITS2, $18 \mathrm{~S}$ and $28 \mathrm{~S}$ alignments using the less strict parameters. Sequences of the mitochondrial COI markerwere translated into amino acid chains to ensure no stop-codons were present. COI fragments presenting internal stop codons (and therefore not coding for the protein) were not considered in the analyses. COI uncorrected pairwise distance (P-distance) was calculated within and between species haplotypes from different bores (computed through Molecular Evolutionary Genetics Analysis (MEGA) 7.0 (Kumar et al., 2016) using 1000 bootstraps replications and other parameters unvaried) to compare with former analyses done on bathynellids and other groups of stygofauna.

Gene trees based on each gene alignment, and a phylogeny based on the concatenated alignment of the five genes considered (Concatenate_tree; table 2) were constructed using Bayesian and Maximum Likelihood (ML) method, implemented in RaxML_HPC_BlackBox (Randomized Axelerated Maximum Likelihood, including automatic bootstrapping stop, which calculates the optimal number of replicates to obtain stable support value using the MRE-based bootstrapping criterion (Pattengale et al., 2009), and MrBayes on XSEDE (3.2.6) in the CIPRES Science Gateway online server (Miller et al., 2010), and MrBayes 3.2.5 (Ronquist et al., 2012) respectively. Pilbaranella ethelensis was used as outgroup for all single gene trees, but the ITS2 tree, which was rooted at midpoint. Pilbaranella ethelensis is closely related to the ingroup taxa, but is a distinct genus (Perina et al., 2018). Table 2 summarises the datasets constructed, the best models of nucleotide substitution for each alignment selected by the Akaike information criterion in jModeltest 2.1.9 (Posada, 2008), and the analyses performed.

Automatic Barcode Gap Discovery (ABGD) (Puillandre et al., 2012) and Poisson Tree Processes (PTP) (Zhang et al., 2013) species delimitation methods were implemented, using the online websites (http://wwwabi. snv.jussieu.fr/public/abgd/abgdweb.html and http://sco.h-its.org/exelixis/web/software/ PTP/; 13 March 2019) to evaluate hypothetical species boundaries using phylogenetic trees and alignments listed in table 2. Kimura 80 (K8o) and Jukes-Cantor (JC69) distance, with default values, were used in the ABGD analysis. Trees had distant outgroups removed to improve the results, and were analysed to the PTP method, leaving other settings unvaried.

The molecular phylogeny based on the concatenate tree (Concatenate_tree; table 2) was constructed to explore the phylogenetic relationships among the new species, previously defined taxa from the Pilbara, and publicly available data from other countries to put the 


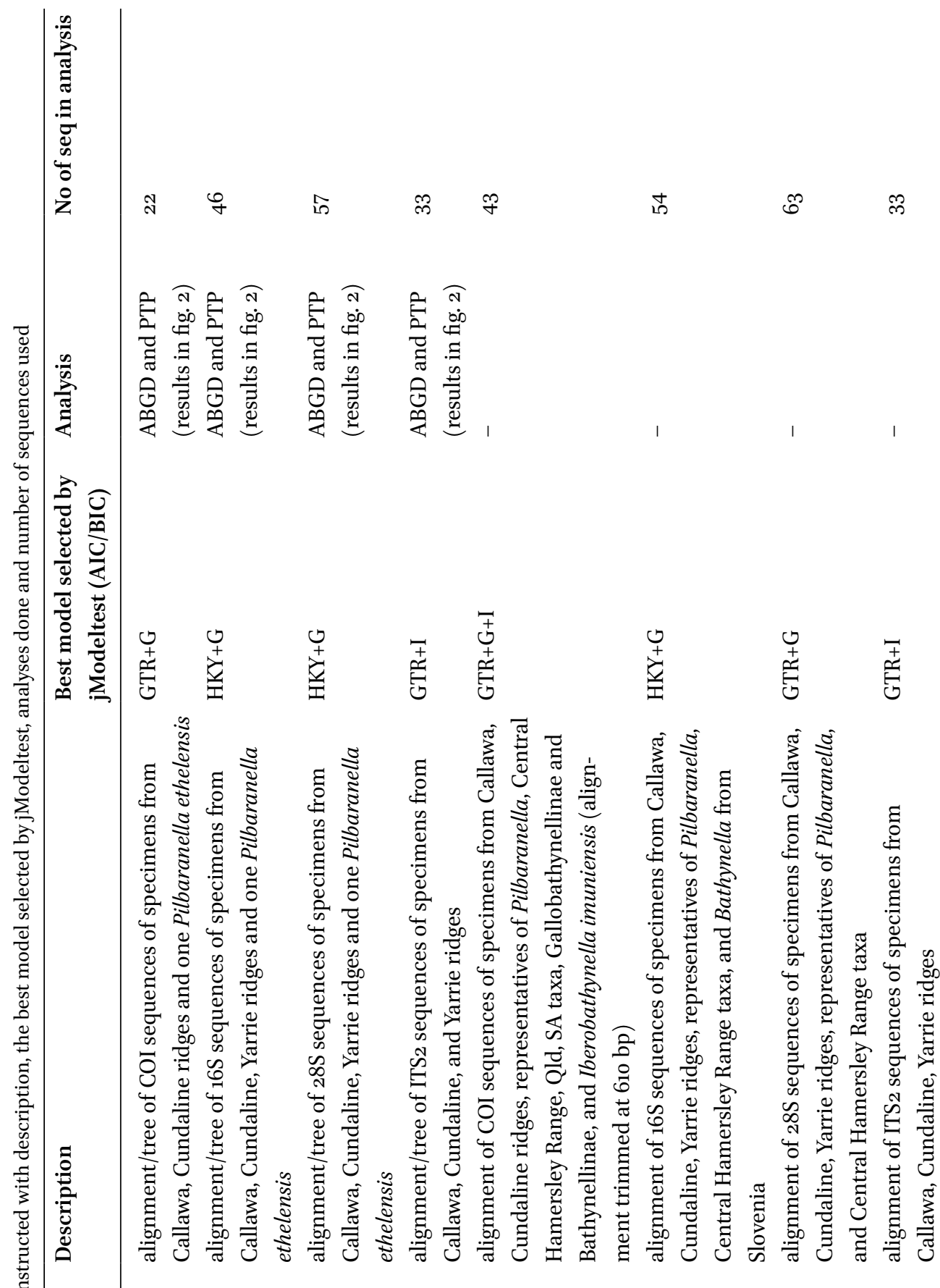


PERINA ET AL.

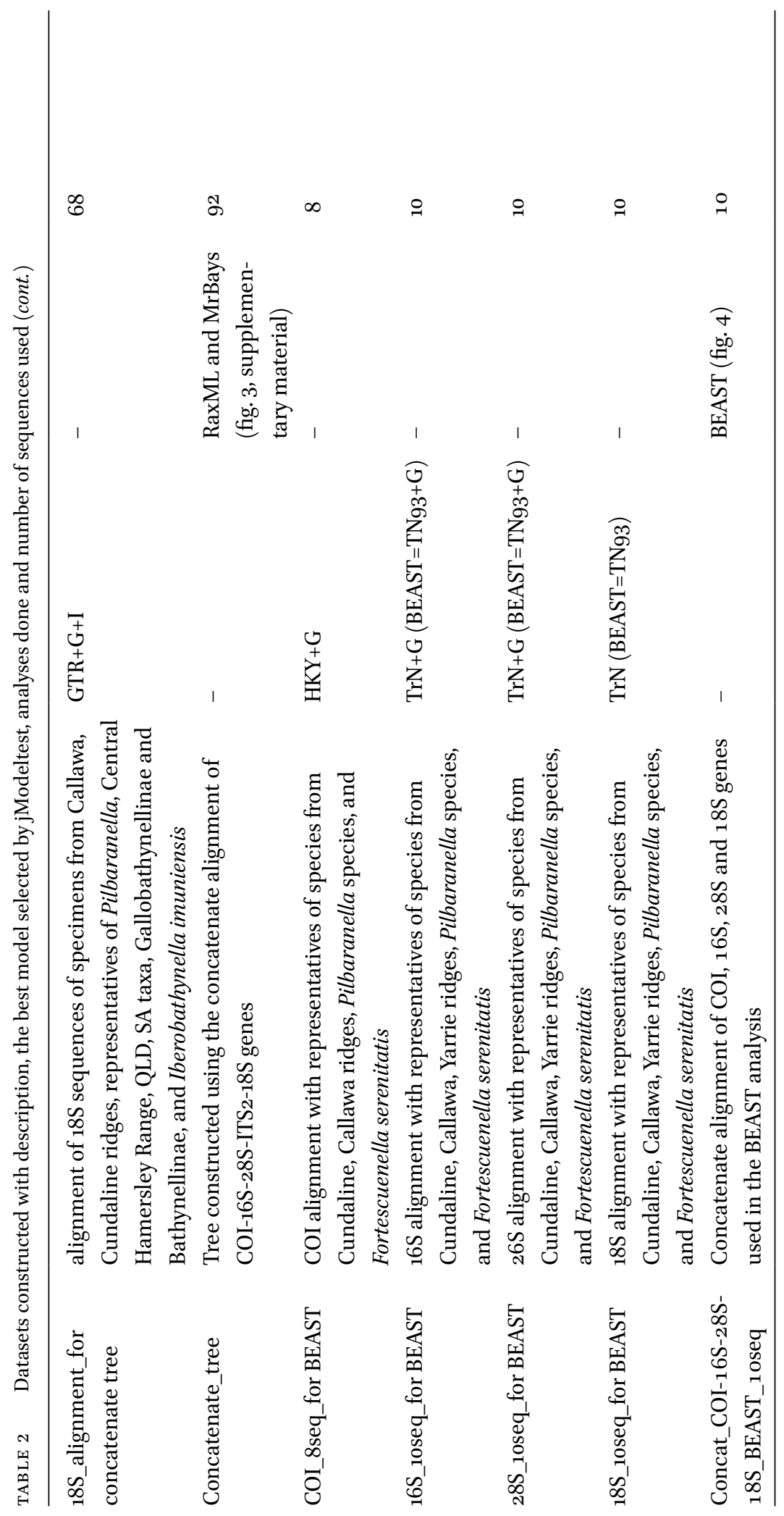


Australian fauna into a worldwide context. Iberobathynella imuniensis (Parabathynellidae) was used as outgroup. The analysis was partitioned by genes with unlinked models. Between 200,000 and 500,000 Markov Chain Monte Carlo (MCMC) generations were run for the single gene trees, and $2 \times 10^{6} \mathrm{MCMC}$ generations were run for the concatenate tree. A burnin fraction of 0.25 was chosen and the consensus tree was built from the remaining trees. The program Tracer 1.6 (Rambaut et al., 2014) was used to assess the convergence of the Bayesian analysis, making sure that the Effective Sample Size (ESS) was above 200.

The time of divergence of the Goldsworthy taxa was estimated to establish the date of the node that represents the ancestor that colonized the perched aquifers, and to establish the origins of Bathynellidae in the area. The analysis was conducted using a Bayesian evolutionary approach implemented in BEAST 2.4.8 program (Bouckaert et al., 2014) run in the CIPRES Science Gateway online server (Miller et al., 2010). The concatenated COI16S-28S-18S alignment used in the analysis included 10 sequences with the most complete dataset. One specimen per species occurring in the study area, representatives of Pilbaranella species, and Fortescuenella serenitatis as outgroup, a distantly related genus within the same bioregion (Perina et al., 2019). In the case of incomplete data, a chimera was assembled using different specimens belonging to the same species. The data were partitioned by gene with unlinked site and clock models, linked trees and Yule model. Nucleotide substitution models selected for each gene by the Akaike information criterion in jModeltest are listed in table 2 . We excluded the proportion of invariant site from the COI, $28 \mathrm{~S}$ and $18 \mathrm{~S}$ models to simplify the analysis and obtain convergence. A relaxed lognormal clock was set for all genes. Since no Bathynellacea fossils are available to calibrate the molecular clock, we utilized $16 \mathrm{~S}$ and COI mean substitution rates calculated using the highest and lowest rate available, for each marker, retrieved from the literature from other crustaceans. The $16 \mathrm{~S}$ divergence rates of $0.53 \%$ and $1.36 \% \mathrm{Ma}$ (Stillman \& Reeb, 2001) and the COI divergence rates of $1.4 \%$ (Knowlton \& Weigt, 1998) and 2.76\% Ma (Wares \& Cunningham, 2001) were used to calculate the ucld.mean and sigma of the analysis. For the $16 \mathrm{~S}$ ucld.mean we chose a normal distribution with mean substitution rate $=0.00473$ and sigma $=0.00126$ (therefore $5 \%$ Quantile $=0.00266$ (corresponding to the $0.533 \%$ divergence rate) and 95\% Quantile = 0.0068 (corresponding to the $1.36 \%$ divergence rate). For the COI ucld.mean we chose a normal distribution with mean substitution rate $=0.0104$ and sigma $=0.00205$ (therefore $5 \%$ Quantile $=0.00703$ (corresponding to the $1.4 \%$ divergence rate) and 95\% Quantile = 0.0138 (corresponding to the $2.76 \%$ divergence rate). The ucld.Stdev of both COI and $16 \mathrm{~S}$ was set as exponential with mean $=1.5$. $5 \times 10^{7}$ Monte Carlo Markov chains (MCMC) were run through BEAST 2.4.8 (Bouckaert et al., 2014) and convergence was assessed using Tracer 1.7 (Rambaut et al., 2018), ensuring the Effective Sample Size (ESS) was above 200. Results of the BEAST analysis were summarized and annotated using TreeAnnotator 2.4.7 (Bouckaert et al., 2014) in a Maximum Clade Credibility tree, setting a $10 \%$ burnin, 0.5 posterior probability limit, and mean node heights. The resulting tree was edited in Figtree 1.4.2 (http://tree.bio.ed.ac.uk/software/ figtree/).

\section{Morphological analysis}

The morphological study follows the methods described in Perina \& Camacho (2016) and Perina et al. (2018). The material is vouchered at the Western Australian Museum (see Appendix 2 for voucher numbers).

We used the terminology proposed by Serban (1972). The morphological and molecular descriptions are based on the type series.

Downloaded from Brill. come //26/2023 12:35:40PM 
Abbreviations used in text and figures after Camacho (1986): Th, thoracopod; A.I, antennule; A.II, antenna; Md, mandible, Mx.I, maxillule and Mx.II maxilla.

\section{Results}

The results revealed the presence of two new genera and four new species. The type species of the two new genera are described in Appendix 1 (Anguillanella callawaensis gen. et sp. nov. and Muccanella cundalinensis gen. et sp. nov.) and for ease of communication, these names are used from this point forward.

\section{Molecular results}

Sixty-five specimens from Callawa, Cundaline and Yarrie ridges were sequenced and included in the phylogeny. The total number of specimens extracted and successfully amplified for each marker are summarised in table 3 . Twenty-one sequences (up to $610 \mathrm{bp}$ ) were obtained for COI. All COI fragments were translated and revealed no stop codons. Forty-five sequences up to $375 \mathrm{bp}$ for the $16 \mathrm{~S}$ mitochondrial fragment, fifty-six sequences of about 1000 bp for $28 \mathrm{~S}$, thirty-three sequences up to $740 \mathrm{bp}$ for ITS2, and forty-three sequences up to 1780 bp for $18 \mathrm{~S}$ were obtained. Sequences

TABLE 3 Number of tested and successfully amplified specimens per marker, and \% of success

\begin{tabular}{lllr}
\hline Marker & $\begin{array}{l}\text { No } \\
\text { specimens } \\
\text { extracted }\end{array}$ & $\begin{array}{l}\text { No specimens } \\
\text { successfully } \\
\text { amplified }\end{array}$ & $\begin{array}{l}\text { \% } \\
\text { success }\end{array}$ \\
\hline COI & 66 & 21 & 31.8 \\
16S & 46 & 45 & 97.8 \\
18Si & 43 & 43 & 100.0 \\
18Sii & 43 & 43 & 100.0 \\
18Siii & 43 & 37 & 86.0 \\
28S & 60 & 56 & $93 \cdot 3$ \\
ITS 2 & 59 & 33 & 55.9 \\
\hline
\end{tabular}

are deposited in GenBank (Appendix 2). The ITS2 locus was sequenced for the first time for bathynellids as a supplementary locus to enable more accurate species delineation. The ITS2 primers used for Anguillanella callawaensis gen. et sp. nov. were also tested on several specimens of Muccanella cundalinensis with no success.

\section{Species delimitation}

Bayesian single gene trees for COI, 16S, 28S, and ITS2 together with the species delimitation results for ABGD (with intraspecific divergence (P) intervals) and PTP are represented in fig. 2. Specimens from Yarrie ridge failed to sequence for COI, while specimens from Cundaline failed to sequence for ITS2. Muccanella cundalinensis was identified by morphology and both PTP and ABGD species delimitation methods applied to COI and 28S, while ABGD method using $16 \mathrm{~S}$ dataset returned two groups.

Anguillanella callawaensis was recognised by morphology and by both methods applied to $28 \mathrm{~S}$ and ITS2. However, ABGD of COI alignment split the species into four $(0.001<\mathrm{P}<$ 0.0129) and two $(0.0215<\mathrm{P}<0.19)$ taxa, ABGD of $16 \mathrm{~S}$ identified five groups $(0.001<\mathrm{P}<0.0077$, with $\mathrm{P}=$ prior intraspecific divergence), and PTP defined three and two groups respectively for COI and $16 \mathrm{~S}$ (fig. 2A-B). Anguillanella sp. 1 was consistently identified by morphological and molecular data; Anguillanella sp. 2 is represented by one specimen only and both methods and all markers identified it as a distinct species, although a morphological comparison was not possible since the only individual was a juvenile.

Results of the COI uncorrected P-distance are shown in table 4 . P-distance among haplotypes from different bores (within the same ridge) ranged between o to $16.3 \%$, and within same bore holes ranged between o to $0.9 \%$ in Anguillanella callawaensis gen. et sp. nov. COI P-distance between and within haplotypes 


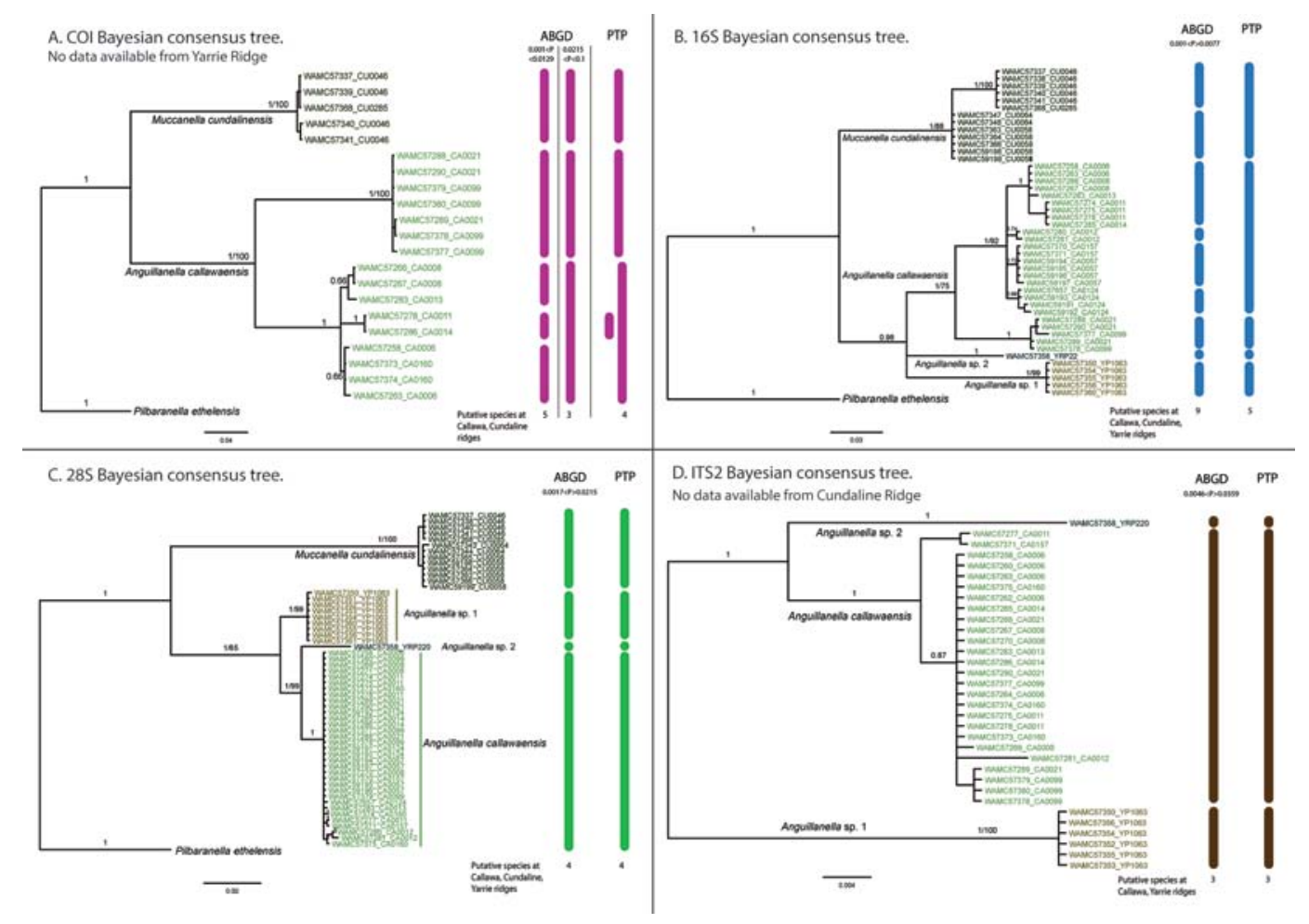

FIGURE 2 Bayesian consensus single gene trees for COI, 16S, $28 \mathrm{~S}$ and ITS2. Numbers on branches represent Bayesian posterior probabilities followed by maximum likelihood bootstrap percentage. ABGD and PTP results are reported next to the trees. ABGD method: major partitions are showed; PTP: partitions with the highest support for each group are represented.

from the same and different bore holes in Muccanella cundalinensis gen. et sp. nov was $0.1 \%$. Supplementary table S1 provides COI $\mathrm{P}$-distances among all sequences obtained from specimens occurring in Callawa and Cundaline ridges. Ten bathynellids from Yarrie ridge were amplified for COI but resulted in contaminations. The mean pairwise distance within Anguillanella callawaensis and Muccanella cundalinensis is respectively 8.9\% and $0.1 \%$, while the mean distance between the two taxa was $20.1 \%$.

\section{Molecular phylogeny}

Maximum likelihood and Bayesian analyses of the concatenated sequences produced slightly different topologies, but both defined by three major monophyletic and well supported groups: Gallobathynellinae and Bathynellinae subfamilies, and the Australian bathynellids (fig. 3 , supplementary fig. S1). The Australian clade is formed by: two taxa from South Australia and two from Queensland, Fortescuenella serenitatis and the other three lineages from the Central Hamersley Range (nr Fortescuenella sp., Bathynellidae indet. from Mount Florence and SVo138), five taxa of Pilbaranella genus, Anguillanella callawaensis gen. et sp. nov., Muccanella cundalinensis gen. et sp. nov., Anguillanella sp. 1 and Anguillanella sp. 2. Muccanella cundalinensis, Anguillanella callawaensis and Anguillanella 


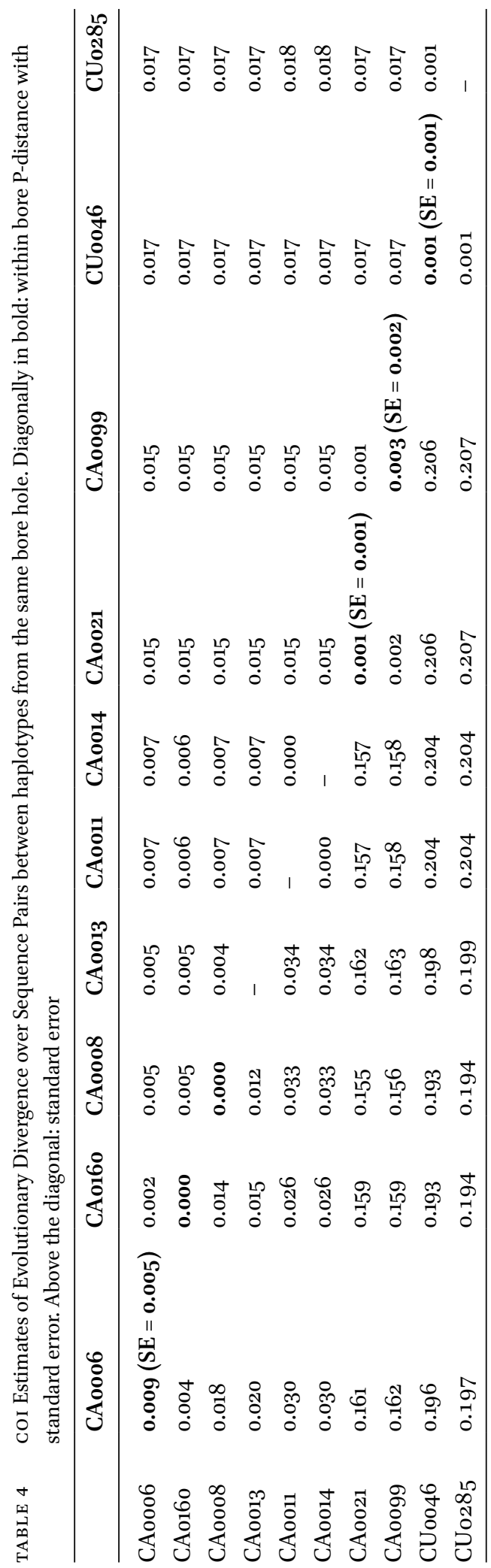

sp. 1 form monophyletic and well-supported lineages (Posterior Probability (PP) comprised between 0.96 and 1 , and bootstrap (BS) comprised between 95 and 100). The two species collected from Yarrie Ridge form a non-supported clade $(\mathrm{PP}=0.72)$ sister to $A n$ guillanella callawaensis, while in the RaxML analysis Anguillanella sp. 1 results sister to Anguillanella callawaensis, but again the node is not supported (BS $=46$, see supplementary fig. $\mathrm{S1})$. Anguillanella genus results sister group with Muccanella cundalinensis $(\mathrm{PP} / \mathrm{BS}=$ 1/100).

The clades formed by: Gallobathynellinae, Bathynellinae, Fortescuenella serenitatis and nr Fortescuenella sp., Bathynellidae from SA, and Bathynellidae from QLD are well supported $(\mathrm{BS}>96, \mathrm{PP}=1)$, but $\mathrm{BS}$ and $\mathrm{PP}$ are quite low at deeper nodes.

\section{Molecular clock analysis}

Figure 4 represents the Maximum Clade Credibility (MCC) tree resulting from the molecular dating analysis. Node bars are represented by height 95\% Higher Posterior Density (HPD). Node ages are indicated above the bars while posterior probability (PP) is below. A chimera was assembled for Pilbaranella sp. C using sequences from two specimens (WAMC57501WAMC60391). The age of the most recent common ancestor (MRCA) between Anguillanella and Muccanella genera is estimated about 64.8 Ma. The mean divergence time of Anguillanella species is 22.6 Ma ago, while Anguillanella callawaensis and Anguillanella sp. 1 result sister species with node age of $15.2 \mathrm{Ma}$. The MRCA of all Pilbaranella species is dated at $34.2 \mathrm{Ma}$ ago, while the most recent possible speciation event between $P$. ethelensis and Pilbaranella possible sp. D dates back to 11.3 Ma. The divergence time between Pilbaranella species and the Goldsworthy taxa is estimated around 96.7 Ma. 


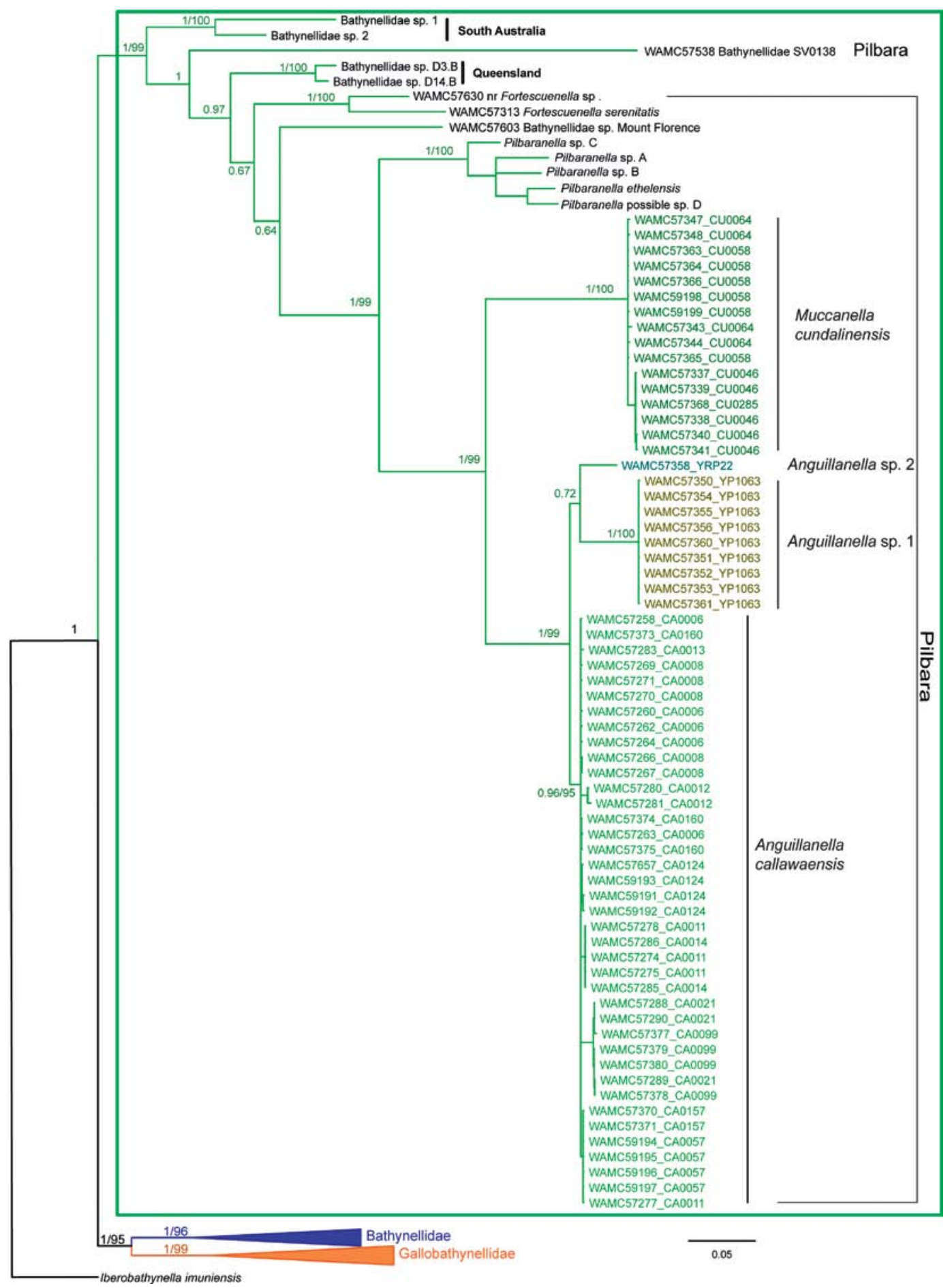

FIGURE 3 Bayesian consensus tree representing the known Bathynellidae taxa constructed using COI, 16S, 28S,

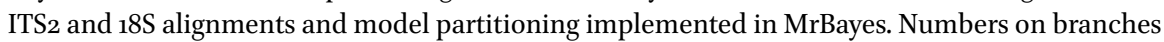
represent Bayesian posterior probabilities followed by maximum likelihood bootstrap percentage. Bathynellinae and Gallobathynellinae clades are collapsed for easier interpretation. 


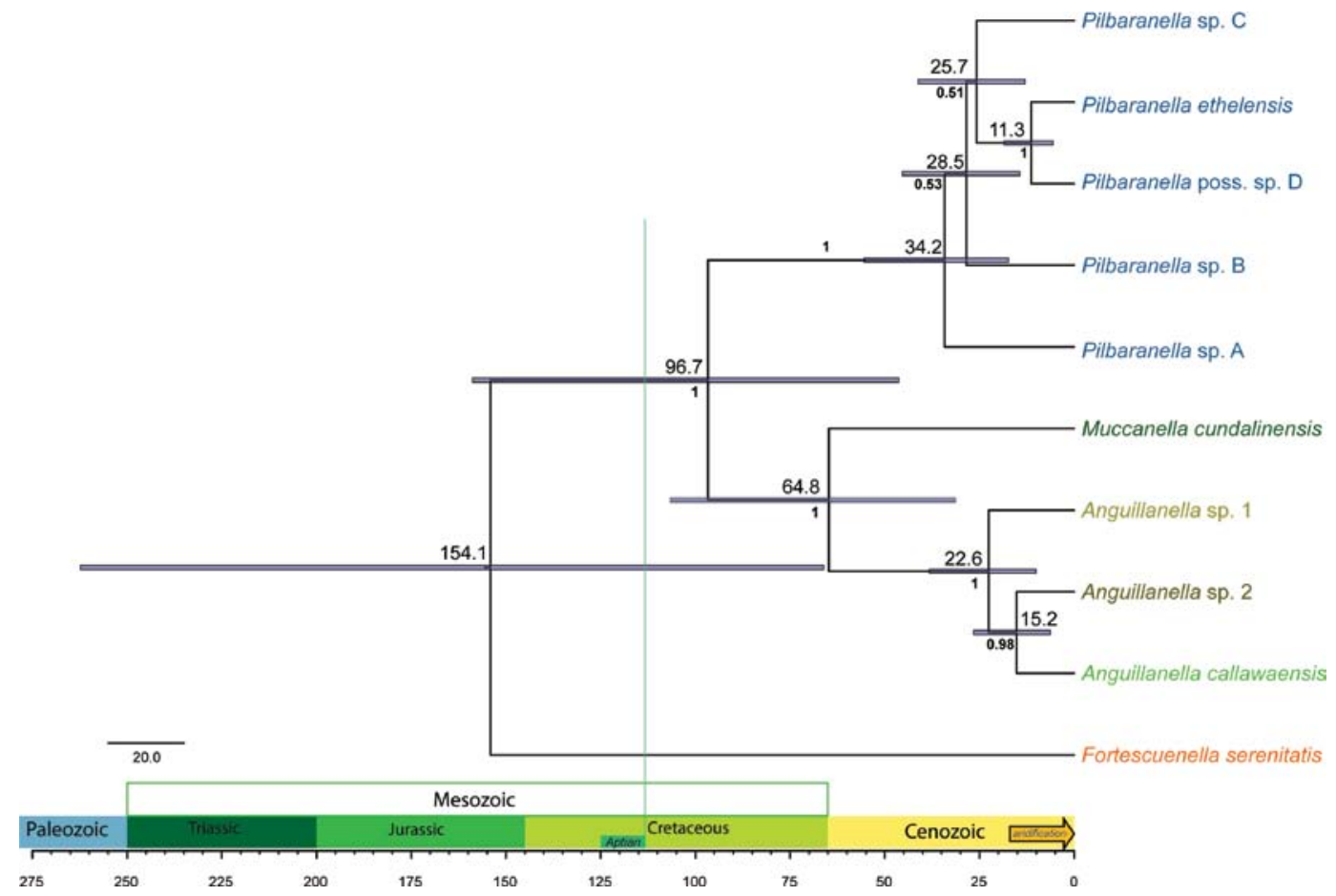

FIGURE 4 Maximum Clade Credibility Tree inferred using a concatenate COI, 16S, 28S and 18S alignment using BEAST. Node bars are 95\% Higher Posterior Density, scale bar is in million years ago (Ma), starting from present 0 . Numbers above bars = node age; numbers below bars (bold) = posterior probability of the node.

\section{Discussion}

\section{De Grey River Bathynellidae diversity}

An abundance of material previously collected during several environmental surveys allowed us to examine the morphological and molecular inter- and intra-specific variability, and describe two new genera, Muccanella cundalinensis gen. et sp. nov. and Anguillanella callawaensis gen. et sp. nov. Although there is a slow discharge of the perched aquifer into the regional one (Dames \& Moore, 1992), the results show different lineages on different ridges, which indicates that stygofauna are isolated in each perched aquifer.

The results of the species delimitation methods adopted here (fig. 2) are supported by morphological analyses, although ABGD and PTP applied to mitochondrial markers recognise different species distributed in different bores (fig. 2A-B). We considered the mitochondrial variability to represent intraspecific population structure (Perina et al., 2018, 2019), and we used the morphological species concept integrated with the above mentioned species delimitation methods. The tree in fig. 3 (Concatenate_tree; table 2) presents the phylogenetic relationships among representatives of known genera and lineages of Bathynellidae and specimens belonging to the new genera. Each genus and species identified is reciprocally monophyletic supporting morphology and species delimitation methods. 
Anguillanella callawaensis occurs in the north-eastern part of Callawa Ridge (fig. 5). The population structure highlighted by the mitochondrial loci is comparable to that found for Pilbaranella ethelensis, with different haplotypes in different bores and similar ones within the same bore. Fortescuenella serenitatis, instead, seems to have a more complex population structure with highly divergent haplotypes (mean COI uncorrected pairwise distance up to $9 \%$ (Perina et al., 2019)) within some bores and the same haplotypes occurring in different bores (see "4 genera networks" in supplementary fig. S2). Despite subtle morphological differences among specimens of Anguillanella callawaensis, and ABGD and PTP methods applied to $28 \mathrm{~S}$ and ITS2, nuclear markers do not recognize different species, the COI uncorrected pairwise distance (P-distance) between specimens occurring in bores CA0o21 and CAoog9 (western side of the ridge) and the ones collected from bores located in the eastern side (CAooo6, CAooo8, CAoon CAoo13, CAoo14 and CAo16o) (fig. 5) is quite high (between 15.6 and $16.5 \%$, see supplementary fig. S2). This "gap" in COI divergences could be due to sampling (the south-western part of the ridge was not sampled, Subterranean Ecology unpublished data) and hence uncertainties remain regarding the distribution of this species, or the two lineages are diverging (perhaps due to hydrogeological discontinuities), but not long enough to be detected by nuclear markers and clear morphological differences. We chose to be conservative and

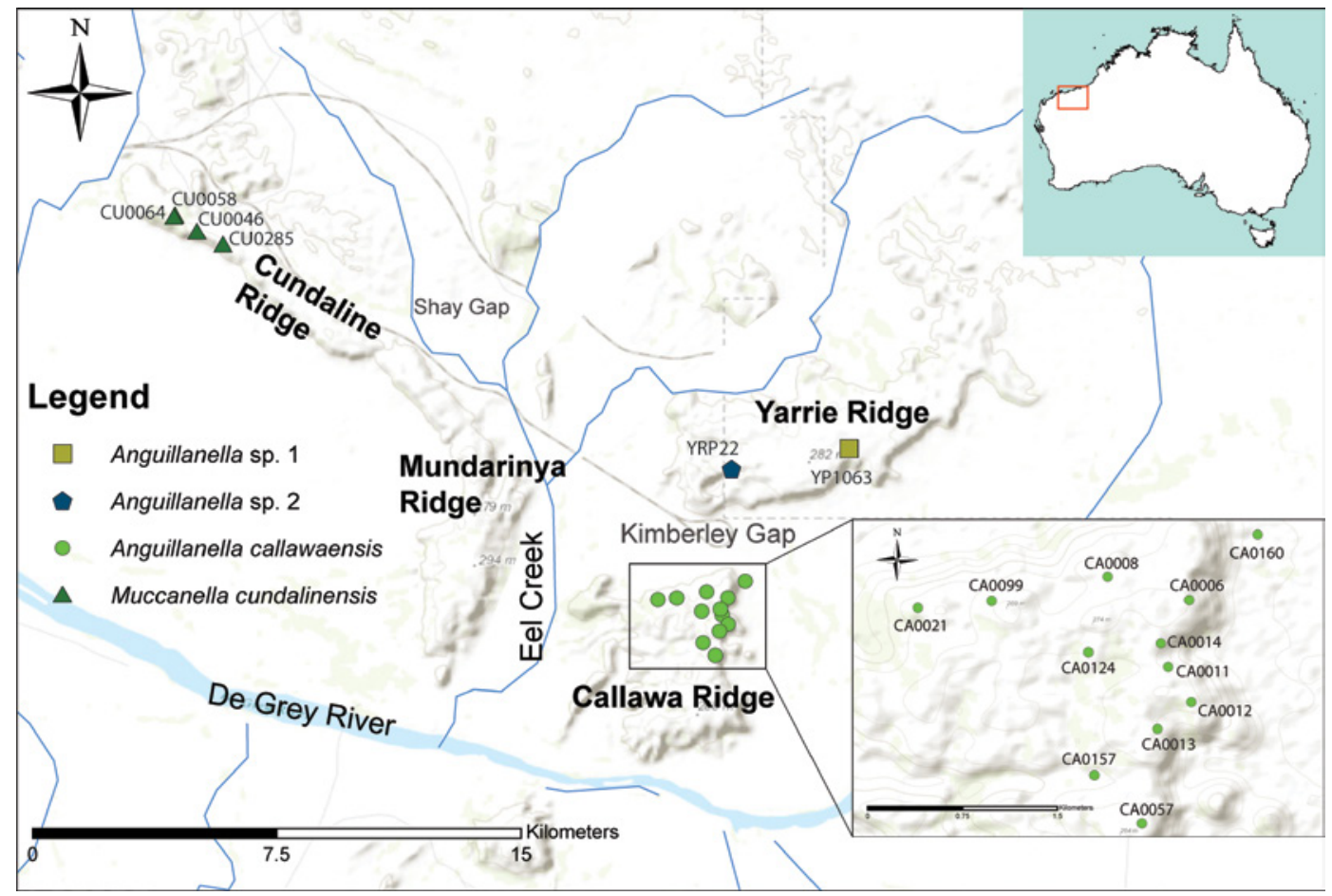

FIGURE 5 Bathynellidae species distribution in the Goldsworthy area (Callawa, Cundaline, Yarrie ridges). 
consider one species, and acknowledge that more study is needed, especially on the hydrogeological connectivity, to better understand the biodiversity and distribution on Callawa Ridge.

Anguillanella sp. 1 and Anguillanella sp. 2 were only found in bore YP1063 and YRP22 respectively at Yarrie Ridge (fig. 5), although other bores in the surrounding area were sampled, excluding the eastern side of the ridge (Subterranean Ecology unpublished data). According to molecular data, these lineages are more closely related to Anguillanella genus, supporting the morphological analysis of Anguillanella sp. 1 (taxon not formally described in this paper), while morphological data for Anguillanella sp. 2 are not available. The presence of multiple species on Yarrie Ridge suggests the possible existence of isolated aquifers within the same plateau.

Muccanella cundalinensis occurs only in the northern part of the Cundaline Ridge (fig. 5), despite broad sampling across the whole plateau (Subterranean Ecology unpublished data). Accordingly the habitat suitable for this group seems to be quite restricted, but additional sampling could reveal a different distribution. Its population structure appears less complicated than Anguillanella callawaensis, probably due to the smaller area where it occurs (less than $2 \mathrm{~km}$ between bores, fig. 5).

As with Pilbaranella ethelensis and Fortescuenella serenitatis in the Fortescue catchment, the four species occurring in the De Grey River have localised distributions, and they can be considered Short Range Endemics, even though distributions might change with more extensive sampling. The 'patchy' nature of sampling for these taxa is demonstrated by Muccanella cundalinensis which was only collected in 2009 surveys and not in previous ones (2007-2008, Subterranean Ecology, unpubl. data) suggesting a possible interannual variability, perhaps connected to flooding events, as storms and rainfalls can change water levels and chemistry and therefore food inflow (Goater, 2009). Similar seasonal dynamics have been observed for some copepod species from the Yilgarn region (Karanovic \& Cooper, 2012). This demonstrates the difficulty and the time frame needed to discover true subterranean biodiversity, and that an absence of taxa resulting from a survey does not necessary mean absence of subterranean fauna.

Once again, previously unstudied aquifers have revealed new taxa of Bathynellidae, confirming the trend of diversification observed for many other stygofaunal groups in the Pilbara, including the Bathynellidae sister family Parabathynellidae (Cho et al., 2005; Hong \& Cho, 2009; Cho \& Humphreys, 2010; Abrams et al., 2012), the Tainisopidae and Phreatoicidae isopods (Knott \& Halse, 1999; Wilson, 2003; Keable \& Wilson, 2006; Finston et al., 2009), oligochaetes (Pinder, 2008; Brown et al., 2015) and the Paramelitidae amphipods (Finston et al., 2007, 2008, 2011).

\section{Allopatric speciation and the origins of bathynellid taxa in the Goldsworthy area}

The aim of this paper was to test the hypothesis that vicariance has shaped the distribution of Bathynellidae in the Goldsworthy area: specifically we wanted to test if one or multiple vicariant events were involved in the diversification of the group. The molecular phylogeny in fig. 3 and clock analysis in fig. 4 show the relationships amongst the taxa occurring in the area (and other lineages) and their divergence times.

All taxa identified in the area are related, forming a monophyletic clade and sharing a common ancestor at $64.8 \mathrm{Ma}$ ago, but 
different divergence times were obtained for Anguillanella species. On this basis we are able to exclude the hypothesis of a single vicariant event responsible for the fragmentation of the common ancestor's area. The date for the most recent common ancestor of the two new genera (at $64.8 \mathrm{Ma}$ ), also allows us to exclude an influence of marine transgression/ regression events, since the latest occurred in the area in the Aptian (125-113 Ma) (see fig. 4). The data suggest that multiple vicariant events fragmented the ancestral population at different times.

\section{Anguillanella and Muccanella origins (64.8}

Ma ago)

In the Upper Cretaceous, a large river system crossing the current Office and Canning Basins was flowing towards the Indian Ocean (BMR Palaeogeographic Group, 1990), and hence we can assume that different rivers were also flowing in the north of the De Grey River. Likewise, from Late Cretaceous to mid Miocene the climate was much wetter (between 70 and $50 \mathrm{Ma}$ ago the average annual rainfall of the Pilbara region was over $200 \mathrm{~cm}$ (González-Álvarez et al., 2016)) with widespread temperate rainforest (Byrne et al., 2008). The valleys between the plateaus were probably filled (or partially filled) with several meters of deposits (probably accumulated during the last marine transgression in the Aptian, such as the Parda Formation (Hickman et al., 1983)), eroded later by flowing water. Examples of extensive erosion can be found in Western Australia in the Yilgarn Craton, where the minimum denudation rate between the end of the Cretaceous and Early Tertiary was about $2.0 \mathrm{~m} \mathrm{Ma}^{-1}$ (Kohn et al., 2002; Humphreys, 2017). The MRCA between Anguillanella and Muccanella suggests that the Eel Creek eroded the deposits faster than other putative creeks between other ridges, isolating the Cundaline population around the end of the Cretaceous, while bathynellid ancestors were still able to move between the perched water on Callawa and Yarrie ridges. The depth of the Eel Creek valley is 13 to $24 \mathrm{~m}$ deeper than the Kimberley Gap between Callawa and Yarrie (depths obtained from Google Earth Pro software), which supports the hypothesis of a faster erosion and therefore an earlier isolation of Cundaline stygofauna.

Anguillanella species origins (22.6-15.2 Ma ago)

The relationships among taxa of this genus are not well resolved. The nodes representing the ancestors of Anguillanella are well supported in the BEAST analysis ( $\mathrm{PP}=1$ and 0.98 , fig. 4), but the error bars largely overlap. The tree in fig. 3 shows a different topology, with Anguillanella sp. 1 and Anguillanella sp. 2 sister species, but with a low node support $(\mathrm{PP}=0.72)$. The single-gene trees also represent different topologies where nuclear markers support the relationship between Anguillanella callawaensis and Anguillanella sp. 2, while the $16 \mathrm{~S}$ results in a trichotomy (fig. 2). These relationships could represent a polytomy, which implies that the hydrological connection (higher water table) that allowed the colonization of the perched water on Callawa and Yarrie ridges from a common ancestor, stopped between 22.6 and 15.2 Ma ago, isolating the three Anguillanella species at similar time (one vicariant event, such as water table drop, perhaps coinciding with the start of the aridification processes (Byrne et al., 2008)).

Two scenarios could, instead, explain the data if Anguillanella callawaensis and Anguillanella sp. 2 are "true" sister species (as shown in fig. 4). The first explanation is one of vicariance: the connection with Anguillanella 
sp. 1 ceased 22.6 Ma ago, while the hydrological connectivity between the western side of Yarrie and Callawa ridges persisted longer. The presence of faults within the Yarrie Ridge (Dames \& Moore, 1992) could explain the interruption of the connectivity in the early Miocene (22.6 Ma). The MRCA between Anguillanella callawaensis and Anguillanella sp. 2 is dated at $15.2 \mathrm{Ma}$ ago, when aridification processes started in the north of Western Australia (Bowler, 1976; Byrne et al., 2008) and the water table dropped steadily, separating the two species, and successively maintaining the isolation of bathynellid populations. The second explanation draws on complex dispersal processes of Bathynellidae ancestors within Yarrie and between Yarrie and Callawa ridges to explain current distributions. Better understanding of the hydrogeology of the area, past climatic and geological events, additional material and molecular markers will help to resolve the relationships among lineages and clarify the drivers of diversification. Additionally, relationships from other subterranean taxa collected from different ridges in the Goldsworthy area may be instructive, for example two species of Atopobathynella (Parabathynellidae) (Abrams et al., 2012), two troglofauna species of Trinemura silverfish (T. callawae, T. cundalinae) (Smith et al., 2012), and two genera of subterranean carabids (Giachino, Eberhard, Perina in preparation). Molecular clock analyses of these groups could help to clarify the diversification processes involved in the area and support our findings.

\section{Acknowledgements}

This work was supported by: Australian Government's Australian Biological Resources
Study (ABRS), National Taxonomy Research Grant Program (NTRGP); Australian Postgraduate Award (APA) scholarship at Edith Cowan University; Gorgon Barrow Island Net Conservation Benefits Fund; International Conference on Subterranean Biology 2008 Grant; and CGL2015-66571-P project (MINECO/FEDER, Ministerio de Economía y Competitividad, Spain. We would like to thank Carlos Puch, Mia Hiller, Ana Hara, Dr Quinton Burnham, Dr Kat Dawkins and Nicholas Newton for their technical support, and Dr Gaynor Dolman for the help in the lab. We are grateful to Subterranean Ecology and BHP Billiton for Bathynellidae material and data, and to the two anonymous reviewers for their valuable comments.

\section{Disclosure statement}

Mrs Perina was previously employed (20082014) by Subterranean Ecology Pty Ltd. During the course of this study Prof. Horwitz has received research funding from the Wildlife Conservation Society, Rio Tinto, the Australian Government, the State Government of Western Australia, and the Peel Harvey Catchment Council and has held an (uncompensated) position with the Scientific and Technical Review Panel for the Ramsar Convention on Wetlands. Associate Prof. Koenders received funding from the Western Australian Department of Fisheries during the preparation of this paper.

\section{Supplementary material}

Supplementary material is available online at: https://doi.org/10.6o84/m9.figshare. 8863475 


\section{References}

Abrams, K.M., Guzik, M.T., Cooper, S.J.B., Humphreys, W.F., King, R.A., Cho, J.-L. \& Austin, A.D. (2012) What lies beneath: molecular phylogenetics and ancestral state reconstruction of the ancient subterranean Australian Parabathynellidae (Syncarida, Crustacea). Mol. Phylogenet. Evol., 64, 1-15. doi:10.1016/j.ympev.2012.03.010

Barr, T.C. \& Holsinger, J.R. (1985) Speciation in cave faunas. Annu. Rev. Ecol. Syst., 16, 313-337. doi:10.1146/annurev.es.16.110185.001525

BMR Palaeogeographic Group (1990) Australia: Evolution of a Continent. Australian Government Publishing Service, Canberra.

Bouckaert, R., Heled, J., Kühnert, D., Vaughan, T., Wu, C.-H., Xie, D., Suchard, M.A., Rambaut, A. \& Drummond, A. (2014) BEAST 2: a software platform for Bayesian evolutionary analysis. PLoS Biol., 10. doi:org/10.1371/journal.pcbi.1003537

Bowler, J.M. (1976) Aridity in Australia: age, origins and expression in aeolian landforms and sediments. Earth Sci. Rev., 12, 279-310. doi:10.1016/0012-8252(76)90008-8

Brown, L., Finston, T., Humphreys, G., Eberhard, S. \& Pinder, A. (2015) Groundwater oligochaetes show complex genetic patterns of distribution in the Pilbara region of Western Australia. Invertebr. Syst., 29, 405-420. doi:10.1071/IS14037

Byrne, M., Yeates, D.K., Joseph, L., Kearney, M., Bowler, J., Williams, M.A.J., Cooper, S., Donnellan, S.C., Keogh, J.S., Leys, R., Melville, J., Murphy, D.J., Porch, N. \& Wyrwoll, K.H. (2008) Birth of a biome: insights into the assembly and maintenance of the Australian arid zone biota. Mol. Ecol., 17, 4398-4417. doi:10.1111/j.1365-294X.2008.03899.x

Camacho, A.I. (1986) A new species of the genus Hexabathynella (Syncarida, Bathynellacea, Parabathynellidae) from Spain. Bijdr. Dierkd., 56, 123-131.

Camacho, A.I., Dorda, B.A. \& Rey, I. (2013a) Integrating DNA and morphological taxonomy to describe a new species of the family Bathynellidae
(Crustacea, Syncarida) from Spain. Graellsia, 69, 179-200. doi:10.3989/graellsia.2013.v69.086

Camacho, A.I., Dorda, B.A. \& Rey, I. (2013b) Old and new taxonomic tools: description of a new genus and two new species of Bathynellidae from Spain with morphological and molecular characters. J. Nat. Hist., 47, 1-28. doi:10.1080/002 22933.2013.768361

Camacho, A.I., Mas-Peinado, P., Dorda, B.A., Casado, A., Brancelj, A., Knight, L.R.F.D., Hutchins, B., Bou, C., Perina, G. \& Rey, I. (2018) Molecular tools unveil an underestimated diversity in a stygofauna family: a preliminary world phylogeny and an updated morphology of Bathynellidae (Crustacea: Bathynellacea). Zool. J. Linn. Soc.-Lond., 183, 70-96. doi:10.1093/zoolinnean/ zlxo63

Camacho, A.I., Rey, I., Dorda, B.A., Machordom, A. \& Valdecasas, A.G. (2002) A note on the systematic position of the Bathynellacea (Crustacea, Malacostraca) using molecular evidence. Contrib. Zool., 71, 123-129.

Castresana, J. (2000) Selection of conserved blocks from multiple alignments for their use in phylogenetic analysis. Mol. Biol. Evol., 17, 540-552. doi:10.1093/oxfordjournals.molbev.a026334

Cho, J.-L. \& Humphreys, W.F. (2010) Ten new species of the genus Brevisomabathynella Cho, Park and Ranga Reddy, 2006 (Malacostraca, Bathynellacea, Parabathynellidae) from Western Australia. J. Nat. Hist., 44, 993-1079. doi:10.1080/00222930903537066

Cho,J.-L., Park,J.-G. \& Humphreys, W.F. (2005)Anew genus and six new species of the Parabathynellidae (Bathynellacea, Syncarida) from the Kimberley Region, Western Australia.J.Nat.Hist., 39, 2225-2255. doi:10.1080/00222930400014148

Christman, M.C. \& Culver, D.C. (2001) The relationship between cave biodiversity and available habitat. J. Biogeogr., 28, 367-380. doi:10.1046/j.1365-2699.2001.00549.x

Coineau, N. \& Camacho, A.I. (2013) Superorder Syncarida Packard, 1885. In: J.C. von Vaupel Klein, M. Charmantier-Daures \& F.R. Schram 
(Eds.) The Crustacea - Treatise on Zoology Anatomy, Taxonomy, Biology, Volume 4, pp. 357449. Brill, Leiden/Boston.

Cooper, S.J.B., Hinze, S., Leys, R., Watts, C.H.S. \& Humphreys, W.F. (2002) Islands under the desert: molecular systematics and evolutionary origins of stygobitic water beetles (Coleoptera: Dytiscidae) from central Western Australia. Invertebr. Syst., 16, 589-598.

Cooper, S.J.B., Saint, K.M., Taiti, S., Austin, A.D. \& Humphreys, W.F. (2008) Subterranean archipelago: mitochondrial DNA phylogeography of stygobitic isopods (Oniscidea: Haloniscus) from the Yilgarn region of Western Australia. Invertebr. Syst., 22, 195-203. doi:10.1071/ISo 7039

Culver, D. \& Pipan, T. (2008) Caves as islands. In: R. Gillespie (Ed.) Encyclopedia of Islands. University of California Press, Berkeley, CA.

Dames \& Moore (1992) Goldsworthy Extention Project - Phase II - Consultative Environmental Review. Prepared for BHP Iron Ore Limited.

Delamare Deboutteville, C. \& Serban, E. (1973) A propos du genre Austrobathynella (Bathynellacea Malacostraca). Livre du cinquantenaire de l'Istitut de spéléologie "Emile Racovitza". Colloque national spéléologie, Bucarest, 1971, 175-198.

Department of Water (2010) Pilbara regional water plan 2010-2030. Government of Western Australia.

Department of Water (2016) Groundwater assessment of the north-west Hamersley Range (HG62). Perth.

Eberhard, S.M., Halse, S.A., Williams, M., Scanlon, M.D., Cocking, J.S. \& Barron, H.J. (2009). Exploring the relationship between sampling efficiency and short range endemism for groundwater fauna in the Pilbara region, Western Australia. Freshwater Biol., 54, 885-901. doi:10.1111/j.1365-2427.2007.01863.x

Environmental Protection Authority (2003) Guidance for the assessment of environmental factors. Consideration of subterranean fauna in groundwater and caves during environmental impact assessment in Western Australia. Government of Western Australia.

Environmental Protection Authority (2007) Guidance for the assessment of environmental factors. Sampling methods and survey considerations for subterranean fauna in Western Australia. Government of Western Australia.

Environmental Protection Authority (2009) $\mathrm{Cu}-$ ndalineand Callawa Mining Operations. Report and recommendations. Government of Western Australia, Perth.

Finston, T.L., Francis, C.J. \& Johnson, M.S. (2009) Biogeography of the stygobitic isopod Pygolabis (Malacostraca: Tainisopidae) in the Pilbara, Western Australia: evidence for multiple colonisationsof thegroundwater.Mol.Phylogenet.Evol., 52, 448-46o. doi:10.1016/j.ympev.20og.03.0o6

Finston, T.L., Johnson, M.S., Eberhard, S.M., Cocking, J.S., McRae, J.M., Halse, S.A. \& Knott, B. (2011) A new genus and two new species of groundwater paramelitid amphipods from the Pilbara, Western Australia: a combined molecular and morphological approach. Rec. West. Aust. Mus., 26, 154-178. doi:10.18195/issn.03123162.26(2).2011.154-178

Finston, T.L., Johnson, M.S., Humphreys, W.F., Eberhard, S.M. \& Halse, S.A. (2007) Cryptic speciation in two widespread subterranean amphipod genera reflects historical drainage patterns in an ancient landscape. Mol. Ecol., 16, 355-365. doi:10.1111/j.1365-294X.2006.03123.X

Finston, T.L., Johnson, M.S. \& Knott, B. (2008) A new genus and species of stygobitic paramelitid amphipod from the Pilbara, Western Australia. Rec. West. Aust. Mus., 24, 395-410. doi:10.18195/ issn.0312-3162.24(4).2008

Fitts, C.R. (2012) Groundwater Science, Second Edition. Elsevier Science, San Diego.

Foulquier, A., Malard, F., Lefébure, T., Douady, C.J. \& Gibert, J. (2008) The imprint of Quaternary glaciers on the present-day distribution of the obligate groundwater amphipod Niphargus virei (Niphargidae). J. Biogeogr., 35, 552-564. doi:10.1111/j.1365-2699.2007.01795.x 
Giribet, G., Carranza, S., Baguna', J., Riutort, M. \& Ribera, C. (1996) First Molecular Evidence for the existence of a Tardigrada + Arthropoda clade. Mol. Biol. Evol., 13, 76-84. doi:10.1093/oxfordjournals.molbev.a025573

Goater, S.E. (2009) Are Stygofauna Really Protected in Western Australia? PhD thesis. University of Western Australia.

González-Álvarez, I., Salama, W. \& Anand, R.R. (2016) Sea-level changes and buried islands in a complex coastal palaeolandscape in the South of Western Australia: Implications for greenfield mineral exploration. Ore Geol. Rev., 73, 475-499. doi:10.1016/j.oregeorev.2015.10.002

Guzik, M.T., Abrams, K.M., Cooper, S.J.B., Humphreys, W.F., Cho, J.-L. \& Austin, A.D. (2008) Phylogeography of the ancient Parabathynellidae (Crustacea : Bathynellacea) from the Yilgarn region of Western Australia. Invertebr. Syst., 22, 205-216. doi:10.1071/ ISo7040

Halse, S.A. (2018) Subterranean fauna of the arid zone. In: H. Lambers (Ed.) On the Ecology of Australia's Arid Zone, pp. 215-241. Springer International Publishing, Cham.

Harvey, M.S. (2002) Short-range endemism among the Australian fauna: some examples from nonmarine environments. Invertebr. Syst., 16, 555570. doi:10.1071/ISo2009

Helix Molecular Solution (2009) To confirm relationships among bathynellids at Cundaline, Callawa and Yarrie Ridge catchments. Unpublished report.

Hickman, A.H., Chin, R.J. \& Gibson, D.L. (1983) Yarrie Western Australia. 1:250 ooo Geological Series - Explanatory Notes. Department of Resources \& Energy.

Holsinger, J.R. (1988) Troglobites: the evolution of cave-dwelling organisms. Am. Sci., 76, 147153 .

Holsinger, J.R., Carlson, K.R. \& Shaw, D.P. (1997) Biogeographic significance of recently discovered amphipod crustaceans (Stygobromus) in caves of southeastern Alaska and Vancouver
Island. Paper presented at the Proceedings of the 12th International Congress of Speliology, Switzerland.

Holsinger, J.R., Hubbard, D.A. \& Bowman, T.E. (1994) Biogeographic and ecological implications of newly discovered populations of the stygobiont isopod crustacean Antrolana lira Bowman (Cirolanidae). J. Nat. Hist., 28, 10471058. doi:10.1080/00222939400770551

Hong, S.J. \& Cho, J.-L. (2009) Three new species of Billibathynella from Western Australia (Crustacea, Syncarida, Parabathynellidae). J. Nat. Hist., 43, 2365-2390. doi:10.1080/00222930903108702 Humphreys, W.F. (2008) Rising from Down Under: developments in subterranean biodiversity in Australia from a groundwater fauna perspective. Invertebr. Syst., 22, 85. doi:10.1071/ iso7016

Humphreys, W.F. (2017) Australasian subterranean biogeography. In: M.C. Ebach (Ed.) Handbook of Australasian Biogeography. CRC Press, Boca Raton, FL.

Humphreys, W.F., Watts, C.H.S., Cooper, S.J.B. \& Leijs, R. (2009) Groundwater estuaries of salt lakes: buried pools of endemic biodiversity on the western plateau, Australia. Hydrobiologia, 626, 79-95. doi:10.1007/s10750-009-9738-4

Johnson, S.L. \& Wright, A.H. (2001) Central Pilbara groundwater study (Report HG8). Hydrogeological Record Series. Water and Rivers Commission, Perth.

Karanovic, T. \& Cooper, S.J.B. (2011) Molecular and morphological evidence for short range endemism in the Kinnecaris solitaria complex (Copepoda: Parastenocarididae), with descriptions of seven new species. Zootaxa, 3026, 1-64. doi:10.11646/zootaxa.3026.1.1

Karanovic, T. \& Cooper, S.J.B. (2012) Explosive radiation of the genus Schizopera on a small subterranean island in Western Australia (Copepoda: Harpacticoida): unravelling the cases of cryptic speciation, size differentiation and multiple invasions. Invertebr. Syst., 26, 115-192. doi:10.1071/ IS11027 
Katoh, K., Misawa, K., Kuma, K. \& Miyata, T. (2002) MAFFT: a novel method for rapid multiple sequence alignment based on fast Fourier transform. Nucleic Acids Res., 30, 3059-3066.

Keable, S.J. \& Wilson, D.F. (2006) New species of Pygolabis Wilson 2003 (Isopoda: Tainisopidae, Crustacea) from Western Australia. Zootaxa, 1116, 1-27. doi:10.5281/zenodo.171623

Kearse, M., Moir, R., Wilson, A., Stones-Havas, S., Cheung, M., Sturrock, S., Buxton, S., Cooper, A., Markowitz, S., Duran, C., Thierer, T., Ashton, B., Meintjes, P. \& Drummond, A. (2012) Geneious Basic: an integrated and extendable desktop software platform for the organization and analysis of sequence data. Bioinformatics, 28, 1647-1649. doi:10.1093/bioinformatics/ btsig9

Knott, B. \& Halse, S.A. (1999) Pilbarophreatoicus platyarthricus n.gen., n.sp. (Isopoda: Phreatoicidae: Amphisopodidae) from the Pilbara region of Western Australia. Rec. West. Austr. Mus., 51, 33-42. doi:10.3853/j.0067-1975.51.1999 .1291

Knowlton, N. \& Weigt, L.A. (1998) New dates and new rates for divergence across the Isthmus of Panama. P. Roy. Soc. B-Biol. Sci., 265, 2257-2257. doi:10.1098/rspb.1998.0568

Kohn, B.P., Gleadow, A.J.W., Brown, R.W., Gallagher, K., O'Sullivan, P.B. \& Foster, D.A. (2002) Shaping the Australian crust over the last 300 million years: insights from fission track thermotectonic imaging and denudation studies of key terranes. Aust. J. Earth Sci., 49, 697-717. doi:10.1046/j.1440-0952.2002.00942.x

Kumar, S., Stecher, G. \& Tamura, K. (2016) MEGA7: Molecular Evolutionary Genetics Analysis version 7.o for bigger datasets. Mol. Biol. Evol., 33, 1870-1874. doi:10.1093/molbev/msw054

Lamoreaux, J. (2004) Stygobites are more wideranging than troglobites. J. Cave Karst Stud., 66, 18-19.

Little, J., Schmidt, D.J., Cook, B.D., Page, T.J. \& Hughes, J.M. (2016) Diversity and phylogeny of south-east Queensland Bathynellacea. Aust. J. Zool., 64, 36-47. doi:10.1071/ZO16005
Macphail, M.K. \& Stone, M.S. (2004) Age and palaeoenvironmental constraints on the genesis of the Yandi channel iron deposits, Marillana Formation, Pilbara, northwestern Australia*. Aust.J. EarthSci.,51,497-520.doi:10.1111/j.1400-0952.2004 .01071.X

Marmonier, P., Vervier, P., Gibert, J. \& Dole-Olivier, M.-J. (1993) Biodiversity in ground waters. Trends Ecol. Evol., 8, 392-395.

Miller, M.A., Pfeiffer, W. \& Schwartz, T. (2010) Creating the CIPRES Science Gateway for Inference of Large Phylogenetic Trees. Paper presented at the Proceedings of the Gateway Computing Environments Workshop (GCE), New Orleans, LA. doi:10.1109/GCE.2010.5676129

Nunn, G.B., Theisen, B.F., Christensen, B. \& Arctander, P. (1996) Simplicity-correlated size growth of the nuclear $28 \mathrm{~S}$ ribosomal RNA $\mathrm{D}_{3}$ expansion segment in the crustacean order isopoda. J. Mol. Evol., 42, 211-223. doi:10.1007/ BFo2198847

Palumbi, S.R., Martin, A.P., Romano, S., McMillan, W.O., Stice, L. \& Grabowski, G. (1991) The Simples Fool's Guide to PCR. University of Hawaii, Honolulu.

Park, J.-K. \& Foighil, D.Ó. (200o) Sphaeriid and Corbiculid clams represent separate heterodont bivalve radiations into freshwater environments. Mol. Phylogenet. Evol., 14, 75-88. doi:10.1006/ mpev.1999.0691

Pattengale, N.D., Alipour, M., Bininda-Emonds, O.R.P., Moret, B.M.E. \& Stamatakis, A. (2009) How many bootstrap replicates are necessary? In: S. Batzoglou (Ed.) Research in Computational Molecular Biology: Proceedings 13th Annual International Conference, RECOMB 2009, Tucson, AZ, USA, May 18-21, 2009, pp. 184-200. Springer, Berlin/Heidelberg.

Perina, G. \& Camacho, A.I. (2016) Permanent slides for morphological studies of small crustaceans: Serban's method and its variation applied on Bathynellacea (Malacostraca). Crustaceana, 89, 1161-1173. doi:10.1163/15685403-00003576

Perina, G., Camacho, A.I., Huey, J., Horwitz, P. \& Koenders, A. (2018) Understanding subterranean Downloaded from Brill.como4/26/2023 12:35:40PM via free access 
variability: the first genus of Bathynellidae (Bathynellacea, Crustacea) from Western Australia described through a morphological and multigene approach. Invertebr. Syst., 32, 423447. doi:10.1071/IS17004

Perina, G., Camacho, A.I., Huey, J., Horwitz, P. \& Koenders, A. (2019) New Bathynellidae (Crustacea) taxa and their relationships in the Fortescue catchment aquifers of the Pilbara region, Western Australia. Syst. Biodivers., 17, 148-164. doi:10.1080/14772000.2018.1559892

Pinder, A. (2008) Phreodrilidae (Clitellata: Annelida) in north-western Australia with descriptions of two new species. Rec. West. Austr. Mus., 24, 459-468. doi:10.18195/issn.0312-3162.24(4). 2008.459-468

Posada, D. (2008) jModelTest: phylogenetic model averaging. Mol. Biol. Evol., 25, 1253-1256. doi:10.1093/molbev/msno83

Puillandre, N., Lambert, A., Brouillet, S. \& Achaz, G. (2012) ABGD, Automatic Barcode Gap Discovery for primary species delimitation. Mol. Ecol., 21, 1864-1877. doi:10.1111/j.1365-294X.2011. 05239.x

Rambaut, A., Drummond, A.J., Xie, D., Baele, G. \& Suchard, M.A. (2018) Posterior summarization in Bayesian phylogenetics using tracer 1.7. Syst. Biol., 67, 901-904. doi:10.1093/sysbio/syyo32

Rambaut, A., Suchard, M.A., Xie, D. \& Drummond, A.J. (2014) Tracer vı.6. Available online: http:// beast.bio.ed.ac.uk/Tracer.

Rix, M.G. (2009) Taxonomy and Systematics of the Australian Micropholcommatidae (Arachnida: Araneae). PhD thesis. The University of Western Australia, Perth.

Ronquist, F., Teslenko, M., van der Mark, P., Ayres, D.L., Darling, A., Höhna, S., Larget, B., Liu, L., Suchard, M.A. \& Huelsenbeck, J.P. (2012) MrBayes 3.2: Efficient Bayesian phylogenetic inference and model choice across a large model space. Syst. Biol., 61, 539-542. doi:10.1093/ sysbio/syso29

Schminke, H.K. (1973) Evolution, System und Verbreitungsgeschichte der Familie Parabathynellidae (Bathynellacea, Malacostraca). Akad. Wiss.
Lit. Mainz, Math-Nat., Mikrofauna Meeresbodens, 24, 1-192.

Schminke, H.K. (1974) Mesozoic intercontinental relationships as evidenced by bathynellid Crustacea (Syncarida: Malacostraca). Syst. Zool., 23, 157-164.

Sedghi, M. (2016) On the hydraulics of Extensive perched aquifers. Paper presented at the 2nd National Conference of Water Crisis in Iran and the Middle East.

Serban, E. (1972) Bathynella (Podophallocarida, Bathynellacea). Trav. Instit. Spéol. "É. Racovitza", 11, 11-225.

Simon, C., Frati, F., Beckenbach, A., Crespi, B., Liu, H. \& Flook, P. (1994) Evolution, weighting, and phylogenetic utility of mitochondrial genesequences and a compilation of conserved polymerase chain-reaction primers. Ann. Entomol. Soc. Am., 87, 651-701. doi:10.1093/aesa/87.6. 651

Smith, G.B., Eberhard, S.M., Perina, G. \& Finston, T.L. (2012) New species of short range endemic troglobitic silverfish (Zygentoma: Nicoletiidae) from subterranean habitats in Western Australia's semi-arid Pilbara region. Rec. West. Austr. Mus., 27, 101-116. doi:10.18195/ issn.0312-3162.27(2).2012.101-116

Stillman, J. \& Reeb, C. (2001) Molecular phylogeny of Eastern Pacific porcelain crabs, Genera Petrolisthes and Pachycheles, based on the mtDNA 16S rDNA sequence: phylogeographic and systematic implications. Mol. Phylogenet. Evol., 19, 236-245. doi:10.1006/mpev.2001.0924 Sweet, S.S. (1982) A distributional analysis of Epigean populations of Eurycea neotenes in Central Texas, with comments on the origin of troglobitic populations. Herpetologica, 38, 430-444.

Trontelj, P., Douady, C.J., Fišer, C., Gibert, J., Gorički, Š., Lefébure, T., Sket, B. \& Zakšek, V. (2009) A molecular test for cryptic diversity in ground water: how large are the ranges of macro-stygobionts? Freshwater Biol., 54, 727744. doi:10.1111/j.1365-2427.2007.01877.x

Van de Graaff, W.J.E., Crowe, R.W.A., Bunting, J.A. \& Jackson, M.J. (1977) Relict early Cainozoic Downloaded from Brill.com04/26/2023 12:35:40PM 
drainages in arid Western Australia. Zeitschrift für Geomorphologie, 21, 379-400.

Wares, J.P. \& Cunningham, C.W. (2001) Phylogeography and historical ecology of the north atlantic intertidal. Evolution, 55, 2455-2469. doi:10.1111/j.0014-3820.2001.tboo76o.x

Whiting, M.F., Carpenter, J.M. \& Wheeler, Q.D. (1997) The Stresiptera problem: phylogeny of the holometabolous insect orders inferred from $18 \mathrm{~S}$ and $28 \mathrm{~S}$ ribosomal DNA sequences and morphology. Syst. Biol., 46, 1-68. doi:10.2307/2413635 Williams, I.R. (2003) Yarrie, W.A. (3rd Edition): Western Australia Geological Survey, 1:250,000, Geological Series Explanatory Notes, pp. 84.

Wilson, G.D.F. (2003) A new genus of Tainisopidae fam. nov. (Crustacea: Isopoda) from the
Pilbara, Western Australia. Zootaxa, 245, 1-20. doi:10.11646/zootaxa.245.1.1

WorleyParsons (2012) Pilbara Iron Ore Project Groundwater Impact Assessment Report. Report prepared for Flinders Mine Limited, Perth. Zhang, J., Kapli, P., Pavlidis, P. \& Stamatakis, A. (2013) A general species delimitation method with applications to phylogenetic placements. Bioinformatics, 29, 2869-2876. doi:10.1093/bioin formatics/btt499

RECEIVED: 30 APRIL 2019 | REVISED AND ACCEPTED: 11 JULY 2019

EDITOR: R. VONK 


\section{APPENDIX 1}

\section{Systematic account}

Thirty-nine specimens of Anguillanella callawaensis gen. et sp. nov. were used for DNA extraction and are part of the type series. The extractions were obtained from: 18 whole specimens, and 21 selected body parts (few body segments where no morphological characters are present and/or a piece of the specimen's upper part of pereionites and pleonites). Sixteen specimens of Muccanella cundalinensis gen. et sp. nov. have been used for DNA extraction and are part of the type series. The extractions were obtained from eight whole specimens and eight selected body parts. Selected body parts of nine individuals of Anguillanella sp. 1 gen. nov., and one whole specimen of Anguillanella sp. 2 have been sequenced successfully and used in the molecular study.

\section{Family Bathynellidae Grobben, 1905}

The Family Bathynellidae comprises three subfamilies: Bathynellinae Grobben, 1905, Gallobathynellinae Serban, Coineau \& Delamare Deboutteville, 1971 and Austrobathynellinae Delamare Deboutteville \& Serban, 1973 .

\section{Anguillanella Perina and Camacho gen. nov.} Generic diagnosis

Zoobank: urn:lsid:zoobank.org:act:17 $\mathrm{F}_{7} \mathrm{~F}_{477}{ }^{-6 B} 59^{-}$ 458C-9A43-E3496A17B317

Antennula seven-segmented. Antenna seven-segmented, third endopodial segment very small. Paragnaths with distal strong claws. Mandibular palp three segmented with two long and strong equal barbed claws, and without sexual dimorphism. Pars incisiva with two teeth; processus incisivus accessorius with one tooth and one seta-like tooth; pars molaris with two dentate structures, parallel to main axis of teeth: first structure (closest to processus incisivus accessorius) with four teeth, and second structure formed by a bulb with three to five small denticles. Thoracopods I to VII with epipod and endopod four-segmented. Thoracopod VIII male rectangular and compact, with only one well developed lobe (outer lobe) on penial region (latero external part) and two projections (frontal and posterior); basipod in vertical position with large distal crest; endopod small and exopod large, perpendicular to basipod and curved outward, with simplified morphology and two distal setae present. Female thoracopod VIII simplified: coxopod, without setae; epipod very long; basipod large; one-segmented small ramus (endopod or exopod). Uropod: sympod with four inhomonomous spines and endopod with two spines, one special seta (seta "X") and three more setae (one very short). Furcal rami with five spines.

Type species: Anguillanella callawaensis gen. nov., sp. nov

\section{Anguillanella callawaensis Perina and}

Camacho sp. nov. (figs. 6,7,8-9)

Zoobank: urn:lsid:zoobank.org:act:239940oE-4AA2 $-4697-80$ D6-og25B1DAD43E

Type locality. Bore CAooo8, Callawa Ridge, De Grey River Catchment, Pilbara, Western Australia (see Appendix 3 for borehole coordinates).

\section{Material examined}

Holotype. WAMC57418, male, permanent slide, bore CAooo8, 24 July 2009, Bell (stygo net haul). Allotype. WAMC57370, female, permanent slide, bore CA0157, 10 July 2009, Bell (stygo net haul).

Paratypes. WAMC57258, female, permanent slide, Western Australia, Pilbara, bore CAooo6, 13 June 2009, Bell \& Ridley (stygo net haul); WAMC5726o, female, $100 \%$ ethanol, Western Australia, Pilbara, bore CAooo6, 13 June 2009, Bell \& Ridley (stygo net haul); WAMC57262, female, $100 \%$ ethanol, Western Australia, Pilbara, bore CAooo6, 13 June 2009, Bell \& Ridley (stygo net haul); WAMC57263, sex not recorded, whole specimen for DNA, Western Australia, Pilbara, bore CAooo6, 26 April 2008, Bell 


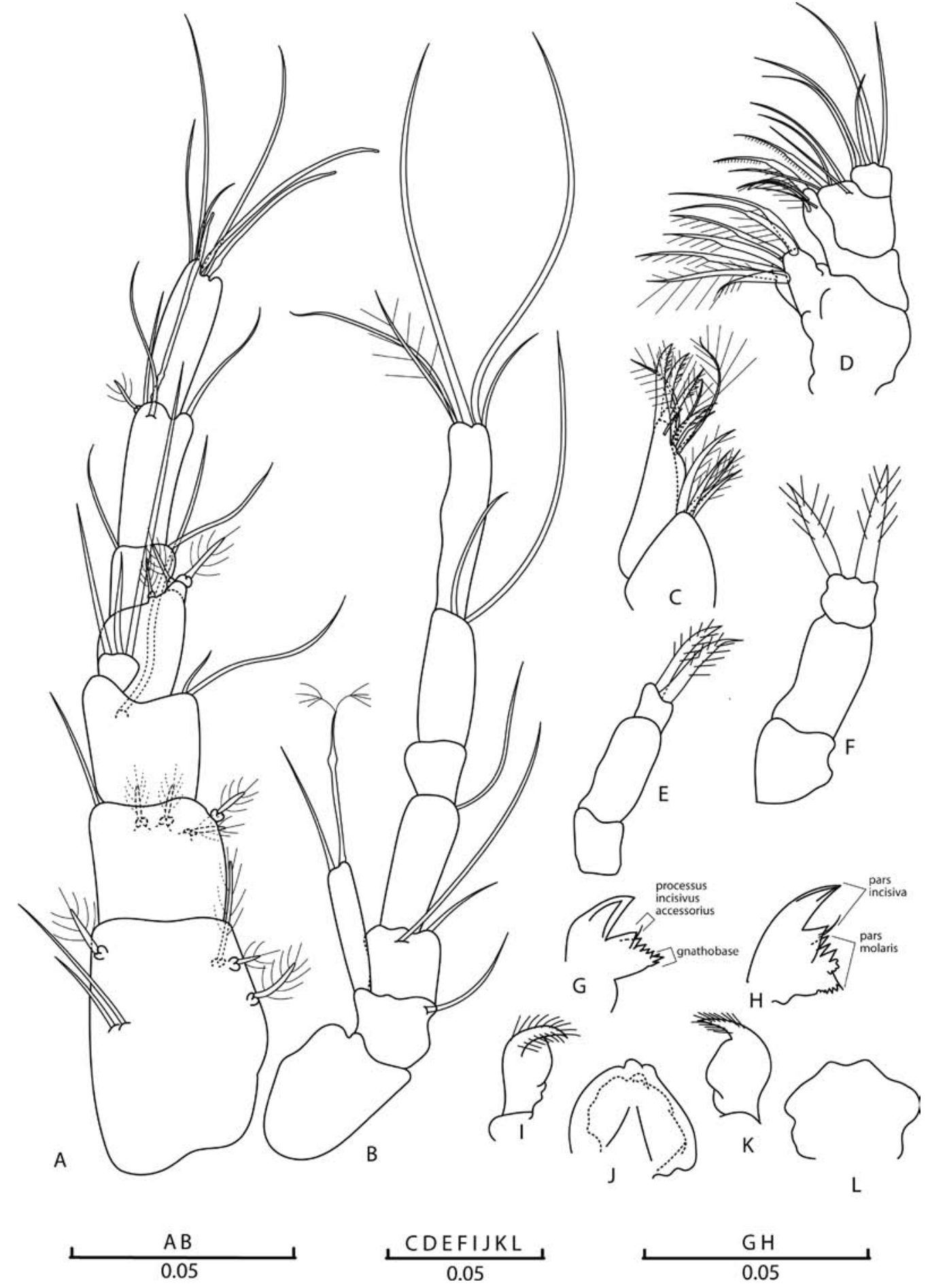

FIGURE 6 Anguillanella callawaensis gen. et sp. nov., male holotype (A-E, G); female allotype (F, H, K, L); male paratype (I, J). (A) Antennula (dorsal view); (B) antenna (dorsal view); (C) max Maxilla; (D) maxillula; (E) mandibular palp male holotype; (F) palp female allotype; (G) mandible male holotype; (H) mandible female allotype; (I) paragnath male WAMC57657 (J) labrum male WAMC57423 (ventral view); (K) Paragnath female allotype; (L) labrum female allotype (dorsabyiew) Scale bar in mm. 


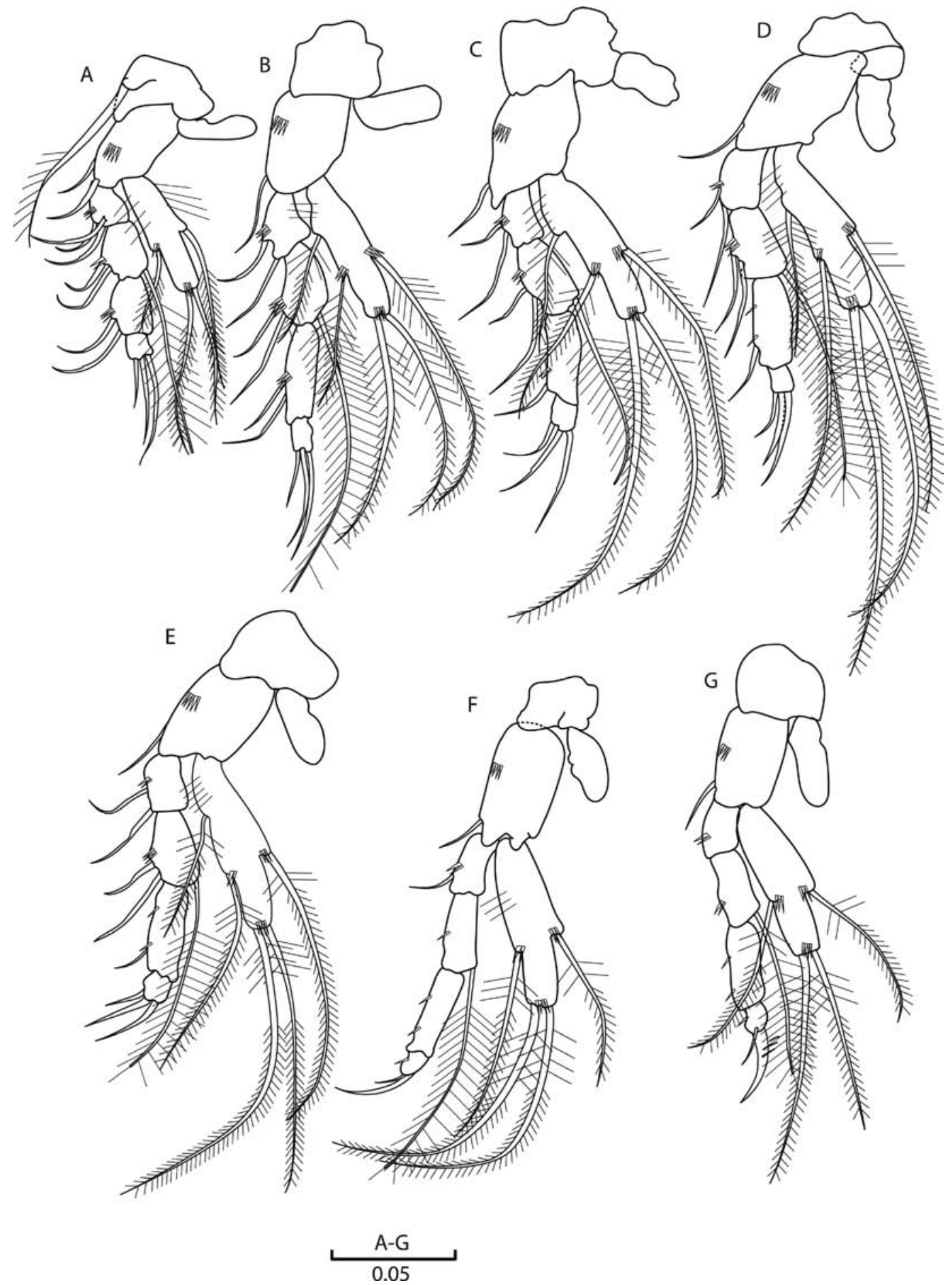

FIGURE 7 Anguillanella callawaensis gen. et sp. nov., male holotype. (A) Thoracopod I; (B) thoracopod II; (C) thoracopod III; (D) thoracopod IV; (E) thoracopod V; (F) Thoracopod VI; (G) thoracopod VII. Scale bar in $\mathrm{mm}$. 


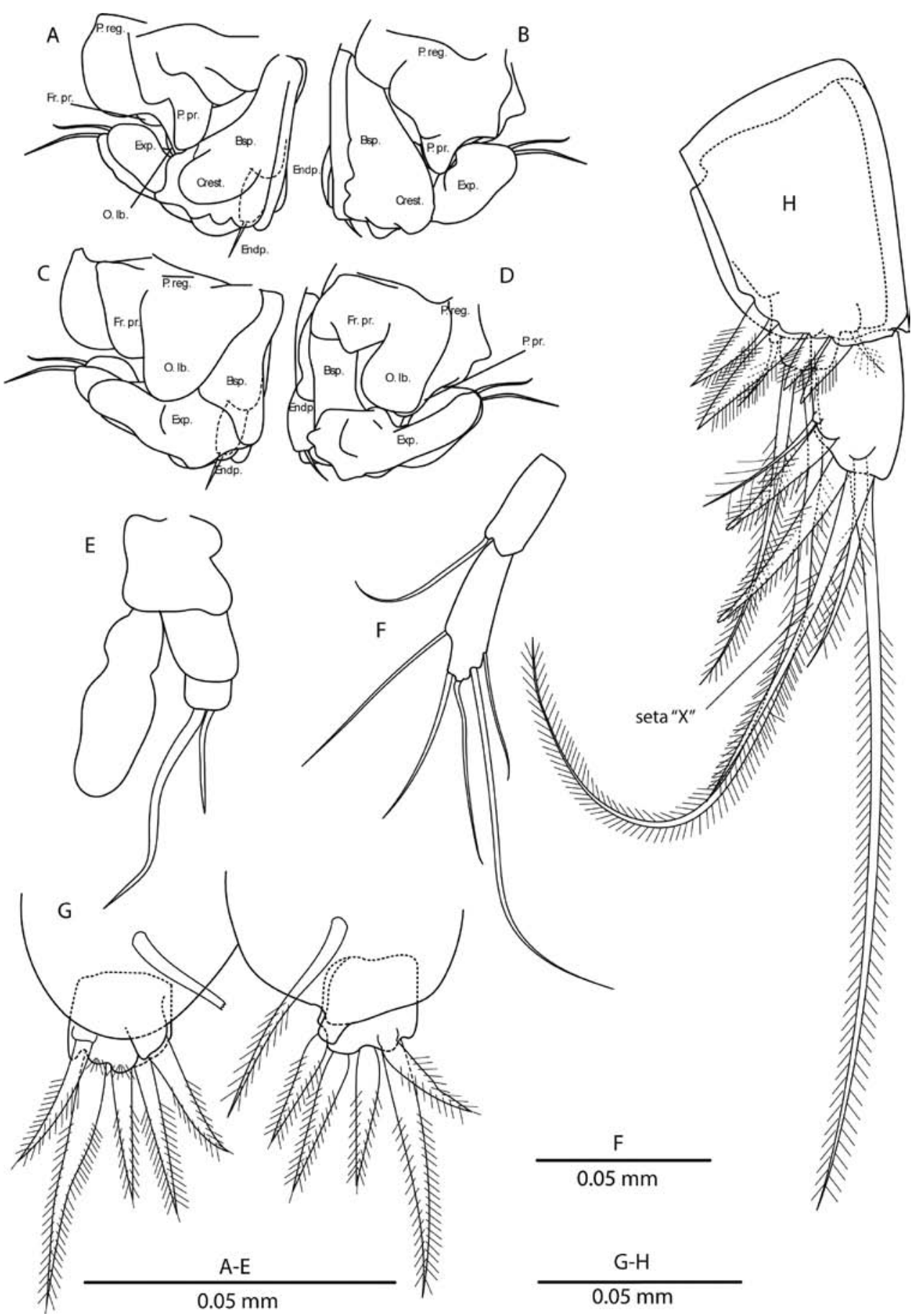

FIGURE 8 Anguillanella callawaensis gen. et sp. nov., (A-D, F, G, H) male holotype. (A, B) thoracopod VIII (posterior view); (C, D) thoracopod VIII (frontal view); (E) thoracopod VIII female allotype (frontal view); (F) first pleopod; (G) furcal rami and dorsal seta (dorsal view); (H) uropod (latero-internal view). Scale bar in mm. Abbreviations: O. lb, outer lobe; Bsp, basipod; Endp, endopod; Exp, exopod; P.pr, posterior projection; Fr.pr, frontal projection. 


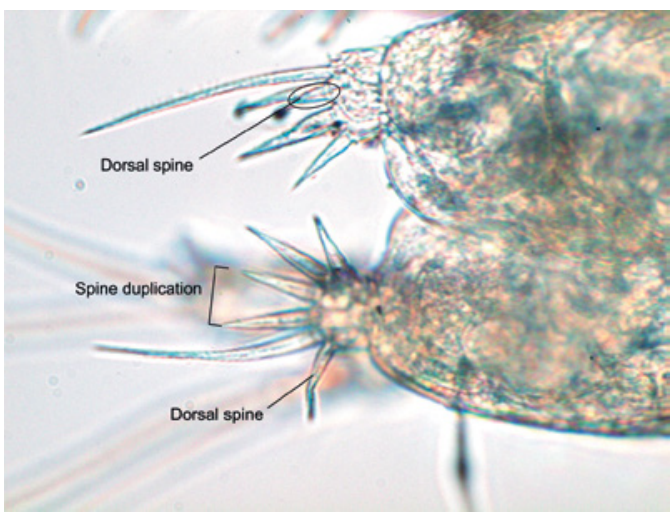

FIGURE 9 Anguillanella callawaensis furca variability (WAMC57370 photo).

\& Eberhard (stygo net haul); WAMC57264, sex not recorded, whole specimen for DNA, Western Australia, Pilbara, bore CAooo6, 26 April 2008, Bell \& Eberhard (stygo net haul); WAMC57266, male, permanent slide, Western Australia, Pilbara, bore CAooo8, o9 July 2009, Bell (stygo net haul); WAMC57267, male, permanent slide, Western Australia, Pilbara, bore CAooo8, o9 July 2009, Bell (stygo net haul); WAMC57269, female, $100 \%$ ethanol, Western Australia, Pilbara, bore CAooo8, 22 July 2009, Bell (stygo net haul); WAMC57270, female, $100 \%$ ethanol, Western Australia, Pilbara, bore CAooo8, 22 July 2009, Bell (stygo net haul); WAMC57271, female, whole specimen for DNA, Western Australia, Pilbara, bore CAooo8, 22 July 2009, Bell (stygo net haul); WAMC57273, female, permanent slide, Western Australia, Pilbara, bore CAoonl, 23 July 2009, Bell (stygo net haul); WAMC57274, sex not recorded, whole specimen for DNA, Western Australia, Pilbara, bore CAoo11, 23 July 2009, Bell (stygo net haul); WAMC 57275, male, permanent slide, Western Australia, Pilbara, bore CAoo11, 23 July 2009, Bell (stygo net haul); WAMC57277, female, 100\% ethanol, Western Australia, Pilbara, bore CAoon, 12 June 2009, Bell \& Ridley (stygo net haul); WAMC57278, male, whole specimen for DNA, Western Australia, Pilbara, bore CAoo11, 12 June 2009, Bell \& Ridley (stygo net haul); WAMC57280, female, permanent slide, Western Australia,
Pilbara, bore CAoo12, 31 May 2009, Bell \& Barnet (stygo net haul); WAMC57281, female, whole specimen for DNA, Western Australia, Pilbara, bore CAoo12, 31 May 2009, Bell \& Barnet (stygo net haul); WAMC57283, female, whole specimen for DNA, Western Australia, Pilbara, bore CAoo13, og July 2009, Bell (stygo net haul); WAMC57285, male, permanent slide, Western Australia, Pilbara, bore CAoo14, og July 2009, Bell (stygo net haul); WAMC57286, female, whole specimen for DNA, Western Australia, Pilbara, bore CA0o14, og July 2009, Bell (stygo net haul);WAMC57288, female, permanent slide, Western Australia, Pilbara, bore CA0o21, 31 May 2009, Bell \& Barnet (stygo net haul); WAMC 57289, female, whole specimen for DNA, Western Australia, Pilbara, bore CAoo21, 31 May 2009, Bell \& Barnet (stygo net haul); WAMC57290, female, whole specimen for DNA, Western Australia, Pilbara, bore CAoo21, 31 May 2009, Bell \& Barnet (stygo net haul); WAMC57371, female, 100\% ethanol, Western Australia, Pilbara, bore CA0157, 10 July 2009, Bell (stygo net haul); WAMC57373, female, $100 \%$ ethanol, Western Australia, Pilbara, bore CA016o, o9 July 2009, Bell (stygo net haul); WAMC57374, juvenile, whole specimen for DNA, Western Australia, Pilbara, bore CA016o, og July 2009, Bell (stygo net haul); WAMC57375, juvenile, whole specimen for DNA, Western Australia, Pilbara, bore CA016o, o9 July 2009, Bell (stygo net haul); WAMC57377, female, $100 \%$ ethanol, Western Australia, Pilbara, bore CAoog9, 13 June 2009, Bell \& Ridley (stygo net haul); WAMC57378, female, $100 \%$ ethanol, Western Australia, Pilbara, bore CAoog9, 13June 2009, Bell \& Ridley (stygo net haul); WAMC57379, male, permanent slide Western Australia, Pilbara, bore CAoog9, 13 June 2009, Bell \& Ridley (stygo net haul); WAMC57380, female, permanent slide Western Australia, Pilbara, bore CAoog9, 13 June 2009, Bell \& Ridley (stygo net haul); WAMC57414, female, permanent slide Western Australia, Pilbara, bore CAooo8 og July 2009, Bell (stygo net haul); WAMC57415, female, permanent slide Western Australia, Pilbara, bore CA0oo8 o9 July 2009, Bell (stygo net haul); 
WAMC57416, sex not identifiable, permanent slide Western Australia, Pilbara, bore CAooo8 o9 July 2009, Bell (stygo net haul); WAMC 57417 , female, permanent slide Western Australia, Pilbara, bore CA0oo8 og July 2009, Bell (stygo net haul); WAMC57419, female, permanent slide Western Australia, Pilbara, bore CAooo8 og July 2009, Bell (stygo net haul); WAMC57420, male, permanent slide Western Australia, Pilbara, bore CAooo8 o9 July 2009, Bell (stygo net haul); WAMC57421, female, permanent slide Western Australia, Pilbara, bore CA0oo8 og July 2009, Bell (stygo net haul); WAMC57422, female, permanent slide Western Australia, Pilbara, bore CAooo8 og July 2009, Bell (stygo net haul); WAMC57423, male, permanent slide Western Australia, Pilbara, bore CAooo8 o9 July 2009, Bell (stygo net haul); WAMC57424, female, permanent slide Western Australia, Pilbara, bore CA0oo8 og July 2009, Bell (stygo net haul); WAMC57425, male, permanent slide Western Australia, Pilbara, bore CAooo8 og July 2009, Bell (stygo net haul); WAMC57426, juvenile, permanent slide Western Australia, Pilbara, bore CAooo8 og July 2009, Bell (stygo net haul); WAMC57657, male, permanent slide, Western Australia, Pilbara, bore CA0124, 14June 2009, Bell \& Ridley (stygo net haul); WAMC59191, female, whole specimen for DNA, Western Australia, Pilbara, bore CA0124, 14 June 2009, Bell \& Ridley (stygo net haul); WAMC59192, sex not recorded, whole specimen for DNA, Western Australia, Pilbara, bore CA0124, 14 June 2009, Bell \& Ridley (stygo net haul); WAMC59193, female, whole specimen for DNA, Western Australia, Pilbara, bore CA0124, 14 June 2009, Bell \& Ridley (stygo net haul); WAMC59194, male, permanent slide, Western Australia, Pilbara, bore CA0057, 23 July 2009, Bell (stygo net haul); WAMC59195, male, permanent slide, Western Australia, Pilbara, bore CA0057, 23 July 2009, Bell (stygo net haul); WAMC59196, female, whole specimen for DNA, Western Australia, Pilbara, bore CA0o57, 23 July 2009, Bell (stygo net haul); WAMC59197, female, whole specimen for DNA, Western Australia, Pilbara, bore CA0057, 23 July 2009, Bell (stygo net haul);
Abbreviations used: Th, thoracopod; A.I, antennule; A.II, antenna; $\mathrm{Md}$, mandible, Mx.I, maxillule and Mx.II maxilla.

\section{Description (based on adults)}

Body. Total length of holotype and allotype $1 \mathrm{~mm}$. Total length of males $0.7-1 \mathrm{~mm}$, and females o.8-1. mm. Body elongated; almost cylindrical, nearly eight times as long as wide; segments slightly widening towards posterior end. Head slightly longer than wide. Pleotelson with one plumose dorsal seta on either side. All drawings are of the holotype and allotype except: paragnath in fig. 6I, and labrum in fig. 6J.

Antennule (fig. 6A). Seven-segmented; length of first three segments slightly longer than the last four; first segment is the longest, then sixth and seventh, as well as second and third, of similar length; fourth small and fifth very small; inner flagellum small and trapezoidal; setation as in fig. 6A; one and two aesthetascs on segments sixth and seventh respectively.

Antenna (fig. 6B). Seven-segmented; as long as the first six segments of A.I; first four segments almost as long as the last three ones; fifth (third of endopod) very small, without setae; terminal segment is the longest; first, fourth and sixth segments similar in length and about 0.8 times as long as seventh segment; setal formula: $0 / 1+\exp / 2+0 / 1+0 / 0 / 2+0 / 5$; exopod about twice as long as second segment, with two terminal setae, one smooth and one bifurcated sensory seta; ventromedial seta absent.

Labrum (fig. 6J, L). Almost square, with smooth free edge, and with two small lobes, more or less developed, on the distal part.

Paragnath (fig. 6I, K). Almost rectangular, strong long claw on distal part with thick setation, distal ventral section slightly dilated.

Mandible (fig. 6E-H). Palp with three segments, terminal segment with two long and strong equal barbed claws, more or less cylindrical without expansions (fig. 6E, F). Masticatory part (fig. 6G, $\mathrm{H}$ ): pars incisiva (incisor process) with two teeth; 
processus incisivus accessorius with one tooth and one seta-like tooth; pars molaris with two dentate structures, parallel to main axis of teeth: first structure (closest to processus incisivus accessorius) with four teeth, and second structure bulbous with three to five small denticles.

Maxillule (fig. 6C). Proximal endite with four setae; distal endite with six teeth, four with denticles and two setae-like, and three plumose setae on the outer margin of endite.

Maxilla (fig. 6D). Four-segmented; setal formula 7, $4,5,5$.

Thoracopods I-VII (fig. 7A-G). Epipod present on Th I to VII. Th I coxa with a long and strong plumose seta; basipod with two smooth setae. Onesegmented exopod, shorter than endopod on all thoracopods; exopod reaches about the middle of the third segment of endopod in all thoracopods; it bears four barbed setae on Th I, Th VI and Th VII, two terminal, one dorsal and one ventral; and five barbed setae on Th III to V. Exopod of thoracopos I to VI with tuft of setules on ventral margin (on dorsal margin too on thoracopod I). Endopod with four segments in all thoracopods, setal formulae (number of setae on basipod in brackets):

Th I: $(2) 3+0 / 2+1 / 2+0 / 3$

Th II: (1) $2+0 / 2+1 / 2+0 / 3$

Th III-IV-V: (1) $2+0 / 2+1 / 1+0 / 3$

Th VI: (1) $1+0 / 0+1 / 0+0 / 2(1)$

Th VII: (1) $0+0 / 0+1 / 0+0 / 2(1)$

Male thoracopod VIII (fig. 8A-D). Small, rectangular and compact, with one lobe (outer lobe) on penial region (latero external part), almost trapezoidal very well developed and larger than the small triangular posterior projection (P. pr.). Small frontal projection (Fr. pr) integrated in penial region does not exceed the outer lobe and the basipod. Basipod vertical with big medial crest on distal end (bigger than O. lb.); endopod small, rectangular, with one short seta; exopod big, with simplified morphology and dilated on distal end, with two terminal setae, and with relatively square base and distal part curved outwardly, almost perpendicular to the main axis of basipod. The latero-internal view (fig. 8A-B) shows the relationship between basipod, exopod and endopod: distal end of basipod bears the endopod, concealed by the crest, and proximal end of basipod embedded near the base of the small penial region.

First pleopod (fig. 8F). Two segmented, first segment with one long seta; second segment with five setae, two distal of similar length and three subdistal unequal setae.

Female allotype thoracopod VIII(fig. 8E). Coxa without setae; basipod almost square; one small ramus, half of the size of basipod, with two setae (one thick and very long); very large epipod, about 2.5 times length of basipod.

Female allotype Th I-VII. Number of segments of endopods and exopods as in male holotype. Number of setae on segments of endopod and basipod differs from male holotype. Setal formulae of allotype (number of setae of basipod in brackets at the start):

Th I: $(2) 3+0 / 2+1 / 2+0 / 3$

Th II: (1) $2+0 / 2+1 / 2+0 / 3$

Th III: (1) $1+0 / 2+1 / 1+0 / 3$

Th IV-V: (1) $2+0 / 2+1 / 1+0 / 3$

Th VI- VII: (1) $0+0 / 0+1 / 0+0 / 2(1)$

Uropods (fig. 8H). Sympod 1.8 times longer than endopod, rectangular, about 1.5 times longer than wide, with four spines: first two distal spines smallest, almost half the length of endopod; third one as long as endopod; and fourth (proximal spine) two-third the length of third spine, but longer than first two distal ones. Endopod with spinous projection on distal outer corner, twice as long as exopod, bearing two strong claws ("uropodial claws" sensu Delamare Deboutteville \& Serban, 1973) (distal claw 1.5 times longer than proximal claw); one "special seta" ("X", which would correspond to the first claw on Bathynella according to Delamare Deboutteville \& Serban, 1973); one plumose seta near the base on the ventral edge; one long terminal 
and one short subterminal seta, ventrally located. Exopod with four setae: two medial setae and two terminal (one very long and thick and the other one short and thinner).

Pleotelson (fig. 8G). With one long, plumose dorsal seta on either side.

Furcal rami (fig. 8G, H). Small, almost square, bearing five spines; dorsal spine as long as second and fourth, third longer than second and first twice the length of second spine.

\section{Variability}

The number of setae on segments of thoracopod endopod and second segment of pleopod vary; pleopod can have five to eight setae on second segment and the same specimen can have left setal formula different from right side. Spines on furca can have different size compare to the holotype; in some specimens the dorsal spine is half of the size of the second spine, and spine duplication can result in six spines on furca (fig. 9).

\section{Etymology}

The genus name comes from the Latin translation of Eel creek (Eel = Anguilla), which separates Callawa from Cundaline ridge. Substantive in opposition. The species name derives from the Callawa ridge where the species was collected.

\section{Muccanella Perina and Camacho gen. nov.}

Generic diagnosis

Zoobank: urn:lsid:zoobank.org:act:24FC9F $35-6 \mathrm{C}_{73}$ -4B99-AD19-C953E813EB7F

Antennula seven-segmented. Antenna sevensegmented; third endopodial segment very small. Paragnaths with distal strong claws. Mandibular palp without sexual dimorphisms. Setae of mandibular palp similar in both sexes. Endopod of thoracopods I to VII four-segmented. Male thoracopod VIII compact and trapezoidal with only one small lobe (outer lobe) on penial region (latero external part) and two small projections (frontal and posterior); large rectangular basipod in vertical position with small distal crest; endopod small with one short seta; exopod perpendicular to principal axis of basipod, bearing two distal setae of similar length. Female thoracopod VIII simplified: coxopod without setae; long epipod; basipod slightly longer than coxopod bearing one seta; two-segmented ramus as long as basipod, with two distal setae: one short and one long. Uropod: sympod with four strong and big subequal spines, endopod with two spines, one "special" seta and three more setae. Furcal rami with five spines.

Type species: Muccanella cundalinensis gen. nov., sp. nov

\section{Muccanella cundalinensis Perina and \\ Camacho sp. nov. (figs. 10-12)}

Zoobank: urn:lsid:zoobank.org:act:42CAEBC 3 -AE 62-4346-9C20-EoEoAE64DCFC

Type locality. Bore CUoo46, Cundaline Ridge, De Grey River Catchment, Pilbara, Western Australia (see appendix 3 for borehole coordinates).

\section{Material examined}

Holotype. WAMC57340, male, permanent slide, bore CUoo46, 29 May 2009, Bell \& Barnet.

Allotype. WAMC57337, female, permanent slide, bore CUoo46, 29 May 2009, Bell \& Barnet.

Paratypes. WAMC57338, female, whole specimen for DNA, bore CUoo46, 29 May 2009, Bell \& Barnet; WAMC57339, female, whole specimen for DNA, bore CUoo46, 29 May 2009, Bell \& Barnet; WAMC57341, female, permanent slide, bore CUoo46, 29 May 2009, Bell \& Barnet; WAMC57343, male, permanent slide, bore CUoo64, 21 July 2009, Bell; WAMC57344, female, whole specimen for DNA, bore CUoo64, 21 July 2009, Bell; WAMC57347, female, permanent slide, bore CUoo64, 21 July 2009, Bell; WAMC57348, male, whole specimen for DNA, bore CUoo64, 21 July 2009, Bell; WAMC 57363, female, permanent slide, bore CUoo58, 29 May 2009, Bell \& Barnet; WAMC57364, male, permanent slide, bore $\mathrm{CU}_{0058,} 29$ May 


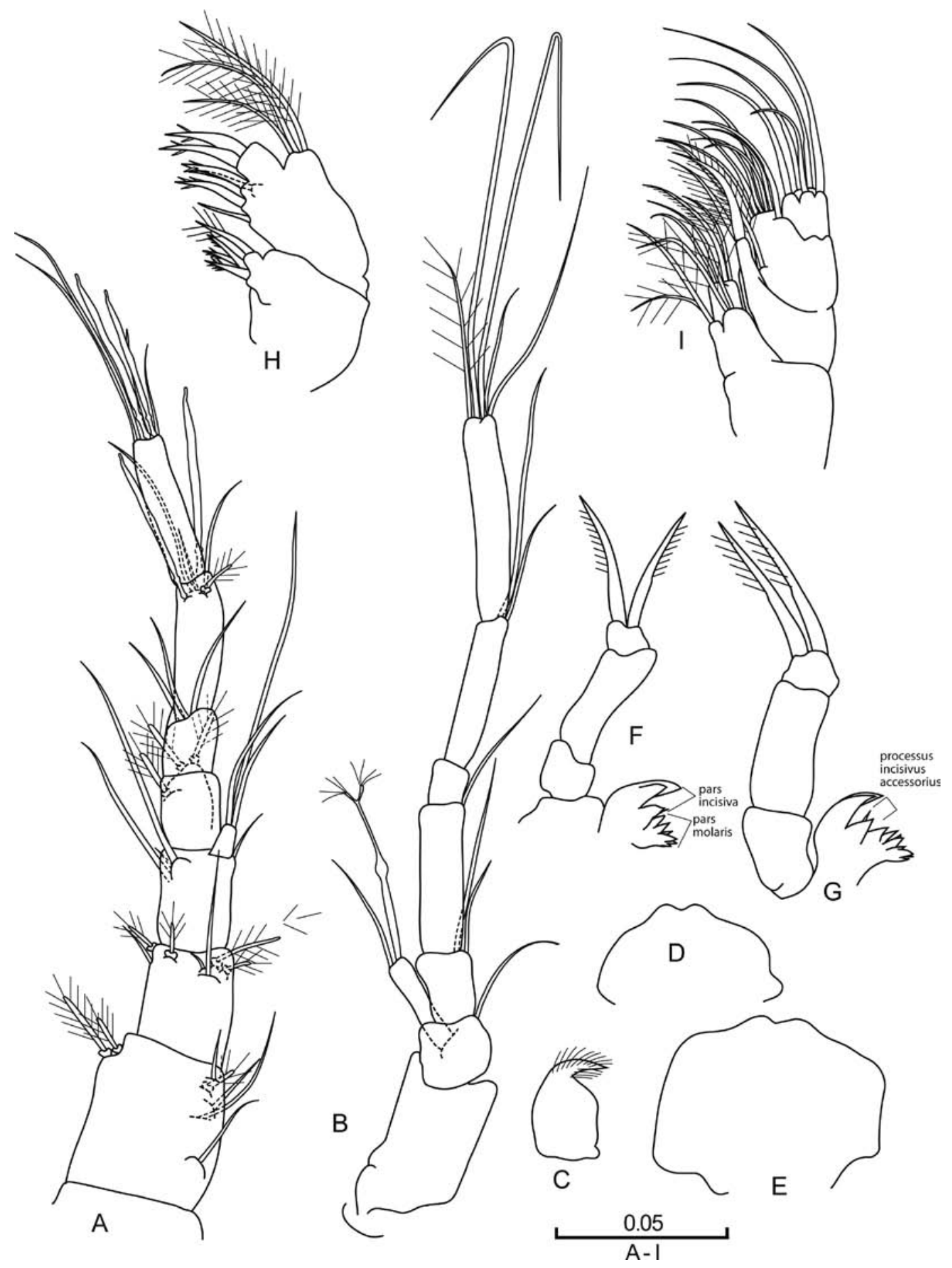

FIGURE 10 Muccanella cundalinensis gen. et sp. nov., male holotype (A, B, D, F, H, I); female allotype (E, G); male paratype (C). (A) Antennula (dorsal view); (B) antenna (dorsal view); (C) Paragnath male WAMC57343; (D) labrum; (E) labrum female WAMC57341; (F) palp and mandible male holotype; (G) palp and mandible female allotype; (H) maxillule; (I) maxilla. Scale bar in $\mathrm{mm}$. 


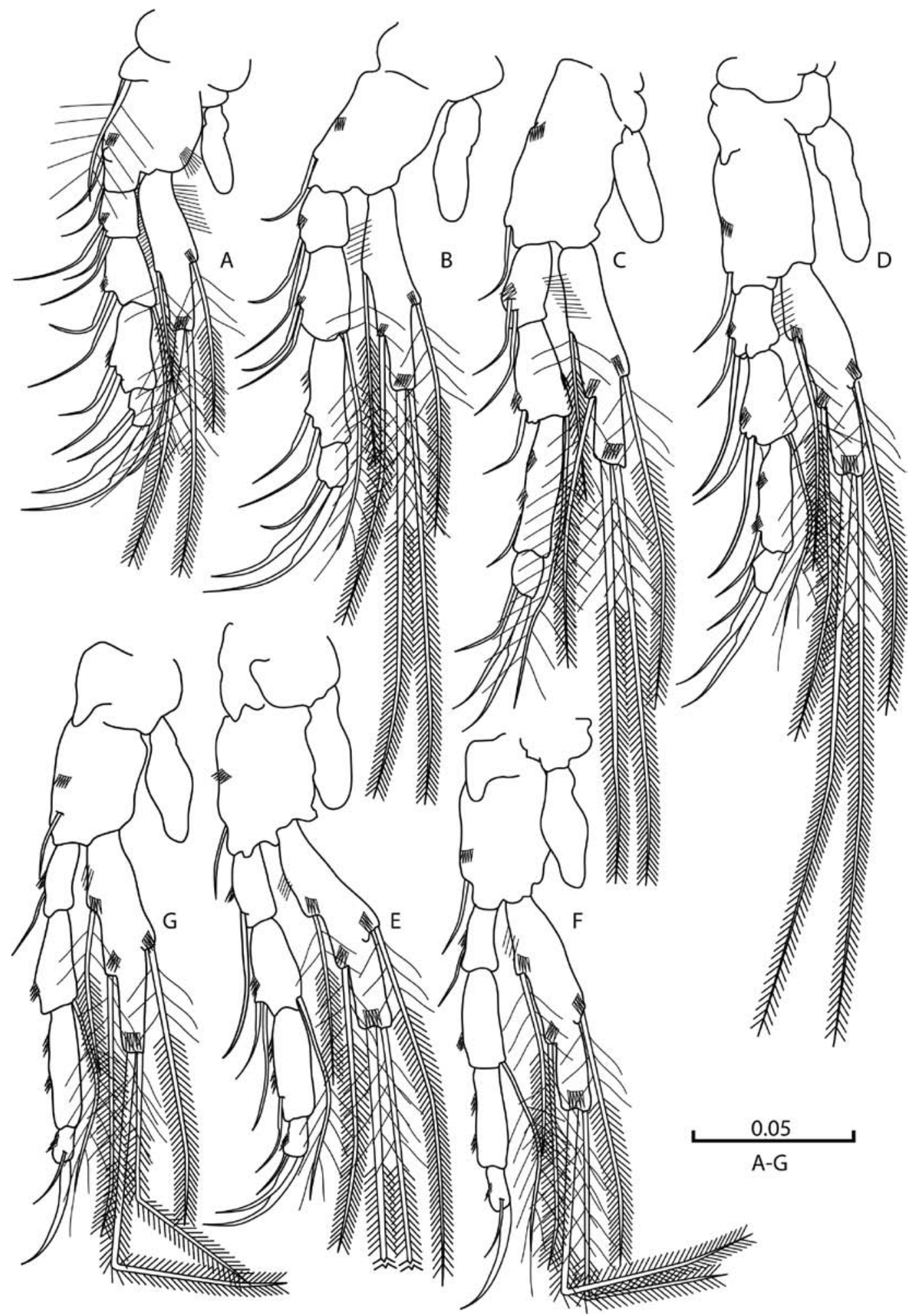

FIGURE 11 Muccanella cundalinensis gen. et sp. nov., male holotype. (A) Thoracopod I; (B) thoracopod II; (C) thoracopod III; (D) thoracopod IV; (E) thoracopod V; (F) ThoracopodVVI; (G) thoracopod VII Scale bar in mism 35 : 40 PM 


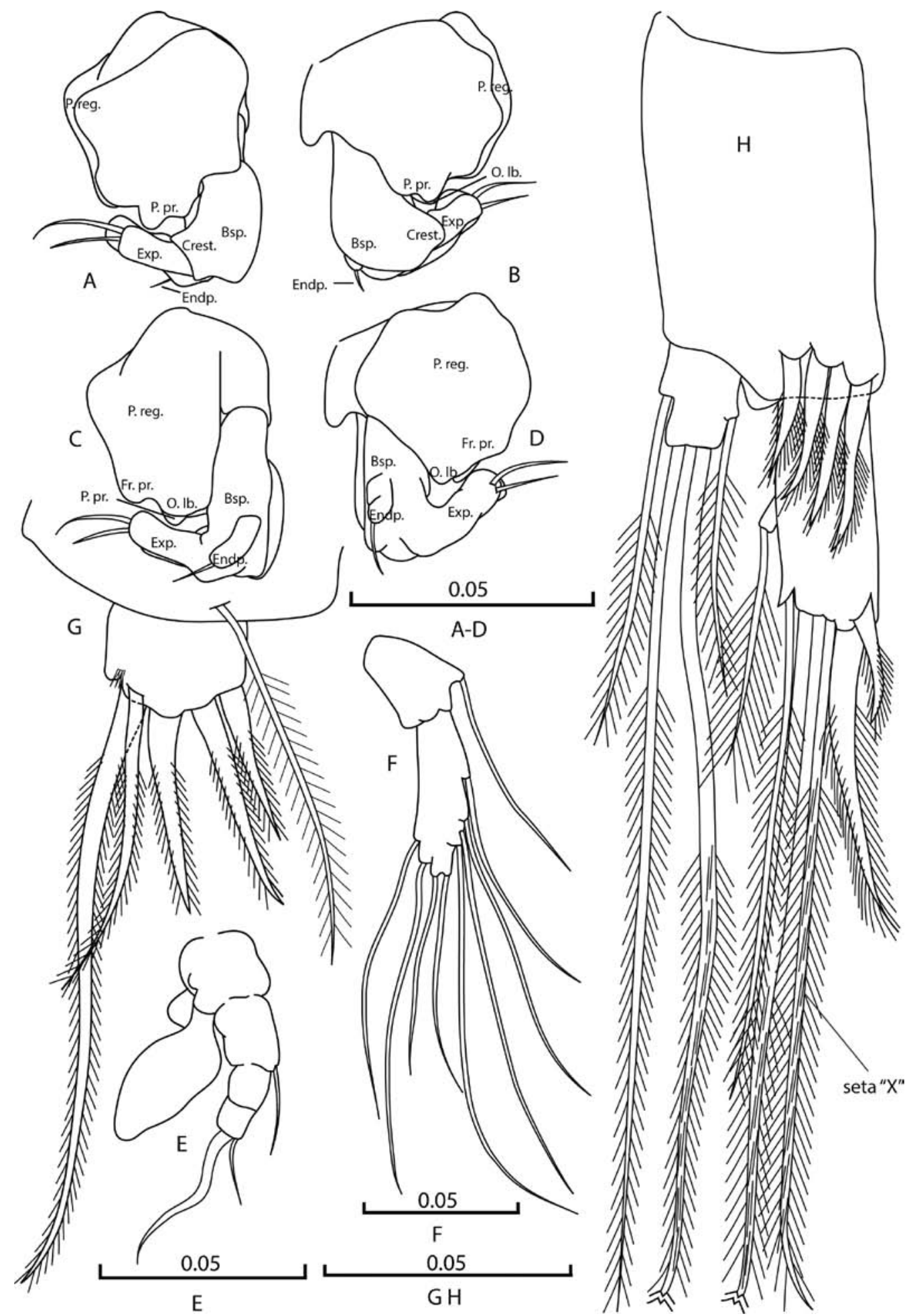

FIGURE 12 Muccanella cundalinensis gen. et sp. nov., (A-D, F-H) male holotype; female allotype (E). (A, B) thoracopod VIII (posterior view); (C, D) thoracopod VIII (frontal view); (E) thoracopod VIII female allotype (frontal view); (F) first pleopod; (G) furcal ramus and dorsal seta (dorsal view); (H) uropod (dorsal

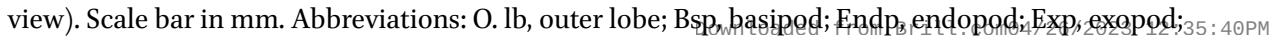
P.pr, posterior projection; Fr.pr, frontal projection. 
2009, Bell \& Barnet; WAMC57365, female, whole specimen for DNA, bore CUoo58, 29 May 2009, Bell \& Barnet; WAMC57366, juvenile, whole specimen for DNA, bore CUoo58, 29 May 2009, Bell \& Barnet; WAMC57368, female, permanent slide, bore CUo285, 30 May 2009, Bell \& Barnet; WAMC 59198, male, permanent slide, bore CUoo58, 10 June 2009, Bell \& Ridley; WAMC59199, sex not recorded, permanent slide, bore CUoo58, 10 June 2009, Bell \& Ridley; WAMC59205, female, permanent slide, bore CUoo58, 29 May 2009, Bell \& Barnet; WAMC59206, male, permanent slide, bore CUoo64, 21 July 2009, Bell; WAMC59207, male, permanent slide, bore CUoo64, 21 July 2009, Bell; WAMC59208, male, permanent slide, bore CUoo64, 21 July 2009, Bell; WAMC59209, male, permanent slide, bore CUo046, 29 May 2009, Bell \& Barnet; WAMC59210, female, permanent slide, bore CUoo46, 29 May 2009, Bell \& Barnet; WAMC59211, male, permanent slide, bore CUoo46, 29 May 2009, Bell \& Barnet; WAMC59212, male, permanent slide, bore CUoo46, 29 May 2009, Bell \& Barnet; WAMC59213, female, permanent slide, bore CUoo46, 29 May 2009, Bell \& Barnet; WAMC59214, male, permanent slide, bore CUoo46, 29 May 2009, Bell \& Barnet; WAMC59215, male, permanent slide, bore CUoo46, 29 May 2009, Bell \& Barnet;

Abbreviations used: Th, thoracopod; A.I, antennule; A.II, antenna; Md, mandible, Mx.I, maxillule and Mx.II maxilla.

\section{Description (based on adults)}

Body. Total length of holotype about $0.95 \mathrm{~mm}$ and allotype $0.94 \mathrm{~mm}$. Total length of males $0.82-1.08$ $\mathrm{mm}$, of females 0.92-1.07 mm. Body almost cylindrical, nearly six times as long as wide; segments slightly widening towards posterior end. Head as long as wide. Pleotelson with one plumose dorsal seta on either side. All drawings are of the holotype and allotype except for fig. 10C, E.

Antennule (fig. 10A). Seven-segmented; length of first three segments as long as the last three; first and last segments are the longest, then sixth, second and third of similar length and fourth slightly shorter, fifth very small; inner flagellum small and longer than wide; setation as in fig. 10A; two aesthetascs on both sixth and seventh segments.

Antenna (fig. 10B). Seven-segmented; nearly as long as A.I; first four segments almost as long as the last three combined; fifth (third of endopod) very small, without setae; terminal segment is the longest, fourth and sixth segments similar in length and about three-fourth the length of seventh segment; setal formula: $0 / 1+\exp / 2+0 / 1+0 / 0 / 2+0 / 5$; exopod 0.8 times the length of the first segment, with two terminal setae, one smooth and one bifurcated sensory seta; ventromedial seta absent. Labrum(fig.10D,E). Almostsquare, with smooth free edge, and with two small lobes on the distal part. Paragnath (fig. 10C). Almost rectangular, strong long claw on distal part with thick setation.

Mandible (fig. 10F, G). Palp with three segments, terminal segment with two long and strong barbed claws of similar length, more or less cylindrical without expansions. Masticatory part: pars incisiva with two teeth; processus incisivus accessorius with one tooth and one seta-like tooth; pars molaris with three teeth close to processus incisivus accessorius and one distal strong tooth with one denticle on each side.

Maxillule (fig. $10 \mathrm{H}$ ). Proximal endite with four setae; distal endite with six teeth, four with denticles and two setae-like, and three plumose setae in outer margin of endite.

Maxilla (fig. 10I). Four-segmented; setal formula 7 , $3,7,5$.

Thoracopods I-VII (fig. 11A-G). Epipod present on Th I to VII. Th I coxa with a long and strong plumose seta and an external bundle of thin hair; basipod with two smooth setae. One-segmented exopod, shorter than endopod on all thoracopods; exopod reaches about the middle of the third segment of endopod in all thoracopods; it bears four barbed setae on Th I, two terminal, one dorsal and one ventral; and five barbed setae on Th II to VII. Exopod of thoracopos I to VI with tuft of setules on ventral margin (on dorsal margin too on thoracopod I). Endopod with four segments in all bownloaded from Brill.com04/26/2023 12:35:40PM 
thoracopods, setal formulae (number of setae on basipod in brackets):

Th I: $(2) 3+0 / 2+1 / 2+0 / 3$

Th II: (1) $2+0 / 2+1 / 2+0 / 3$

Th III: (1) $2+0 / 1-2+1 / 1+0 / 3$

Th IV-V: (1) $2+0 / 2+1 / 1+0 / 3$

Th VI- VII: (1) $1+0 / 0+1 / 0+0 / 2(1)$

Male thoracopod VIII (fig. 12A-D). Compact and trapezoidal, with one small lobe (outer lobe) on penial region (latero external part). Small frontal and posterior projection (Fr. pr; P. pr.) integrated in penial region. Basipod vertical with small crest on distal end; endopod small, rectangular, with one short seta; exopod with simplified morphology, curved outward, almost perpendicular to the main axis of basipod and bearing two setae of slightly unequal length on distal part. Penial region well developed.

First pleopod (fig. 12F). Two segmented, first segment enlarged with one long seta; second segment with eight smooth setae, two distal of similar length and shorter than all the others.

Female allotype thoracopod VIII (fig. 12E). Coxa without setae; basipod rectangular bearing one inner seta; one ramus two-segmented, same size of basipod, with two setae of different length (one thick and very long) on distal end; very large epipod, about twice the length of basipod.

Female allotype Th I-VII. Number of segments of endopods and exopods as in male holotype. Number of setae on segments of endopod and basipod differs from male holotype. Setal formulae of allotype (number of setae of basipod in brackets at the start):

Th I: $(2) 3+0 / 2+1 / 2+0 / 3$

Th II: (1) $2+0 / 2+1 / 2+0 / 3$

Th III: (1) $2+0 / 2+1 / 1+0 / 3$

Th IV-V: (1) $2+0 / 2+1 / 1+0 / 3$

Th VI- VII: (1) $1+0 / 0+1 / 0+0 / 2(1)$

Uropods (fig. $12 \mathrm{H}$ ). Sympod 1.5 times the length of endopod, rectangular, about 1.5 times longer than wide, with four spines of similar length. Endopod with spinous projection on distal outer corner, 2.5 times longer than exopod, with two strong claws ("uropodial claws" sensu Delamare Deboutteville \& Serban, 1973) (distal one 2.5 times longer than proximal one); one "special seta" ("X", which correspond to the first claw on Bathynella according to Delamare Deboutteville \& Serban, 1973); one plumose seta near the base on the ventral edge; one long terminal and one short subterminal seta, longer than distal claw and ventrally located. Exopod with four setae: two medial setae and two terminal (one very long and thick, and one short and thinner).

Pleotelson (fig. $12 \mathrm{G}$ ). With one long, plumose dorsal seta on either side near the base of furca.

Furcal rami (fig. 12G). Small, almost square, bearing five spines; first spine is the longest, about three times the length of the second one; second and third spines of similar length and 2/3 shorter than dorsal one; fourth spine shortest.

\section{Variability}

The number of setae on segments of endopod of thoracopods and second segment of pleopod can vary (usually one more or one less seta).

Etymology

The genus name comes from the name of the station near the type locality: Muccan Station). The species name derives from the Cundaline ridge where the species was collected.

\section{Morphological remarks}

Anguillanella and Muccanella genera share few characters: mandibular palp, mandible, labrum and paragnaths are very similar and also similar to Pilbaranella and Fortescuenella described from the Fortescue catchment (although the mandibular palp of Fortescuenella has claws of slightly different length). All thoracopods of Pilbaranella, Anguillanella and Muccanella have exopod bearing five setae (excluding thoracopod I that has four setae, and thoracopod VI and VII of Anguillanella that also have four). Fortescuenella serenitatis differs from these genera having all exopods of thoracopos bearing four setae, and lacking epipod on thoracopod I.

The structure of the male thoracopod VIII is quite diversean albfour geneva/described fon 


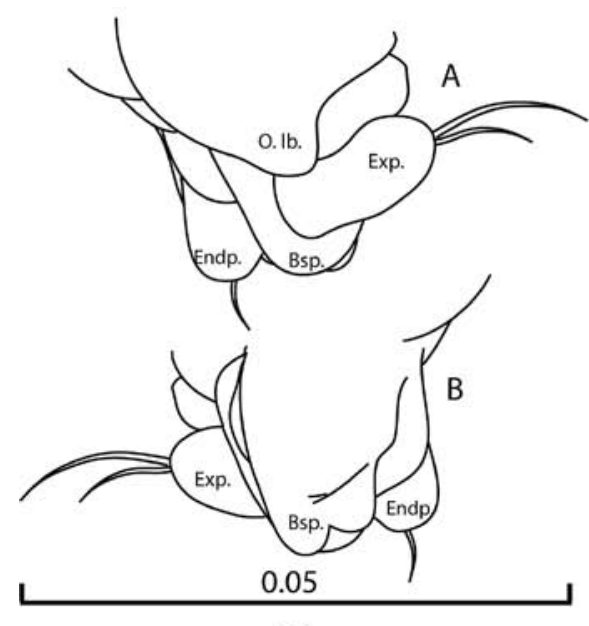

$A B$

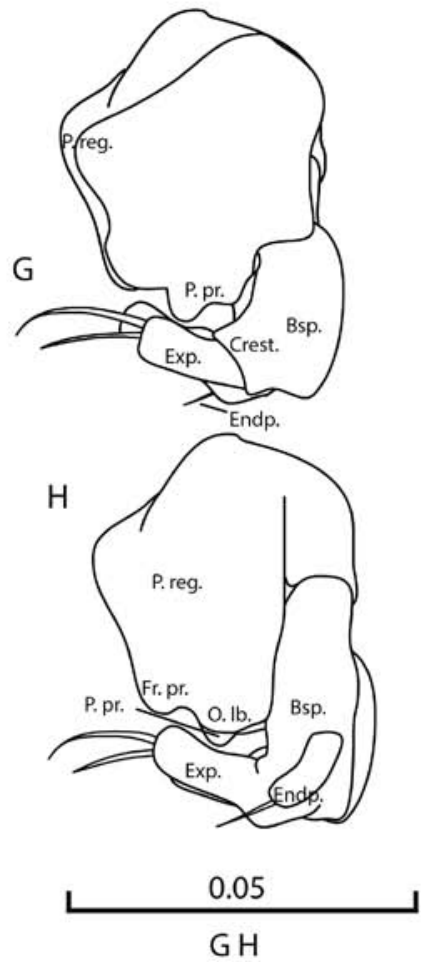

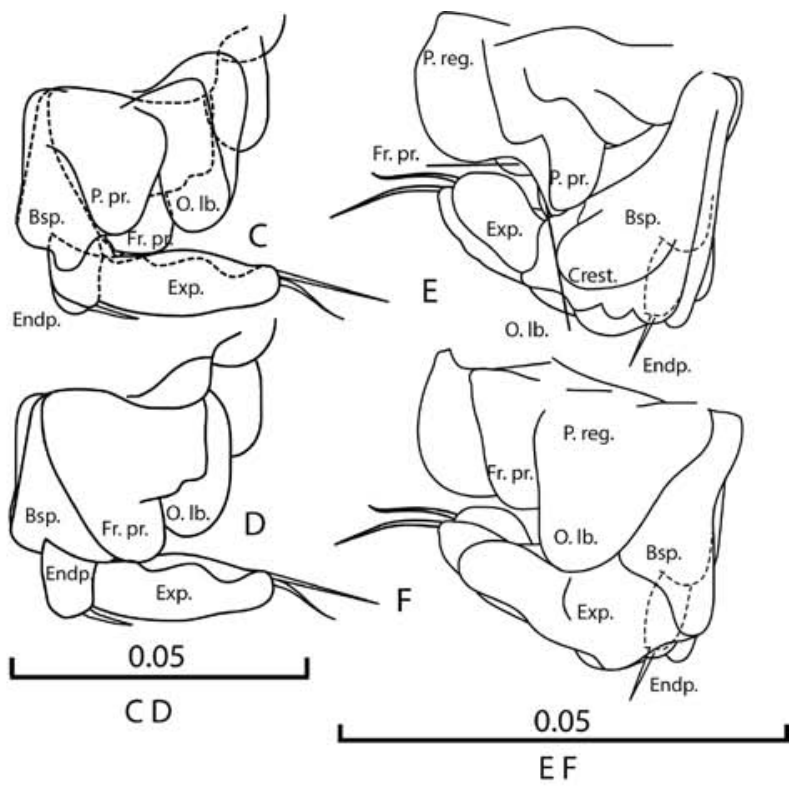
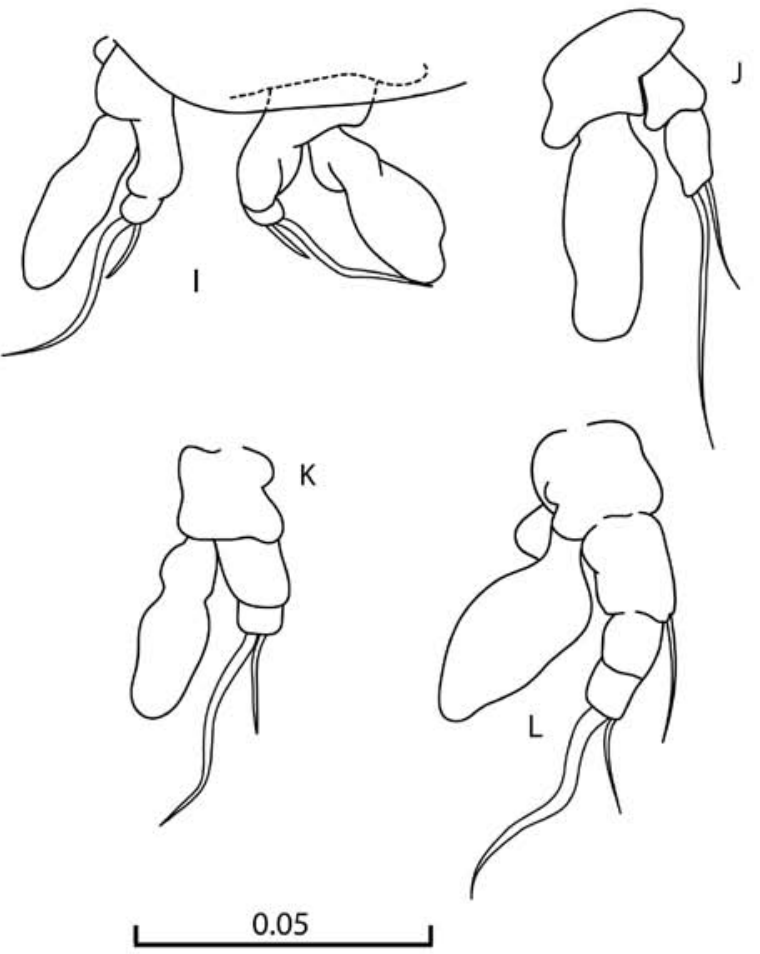

$\mathrm{I}-\mathrm{L}$

FIGURE 13 Male and female thoracopods VIII of the four genera described for WA. (A, B) male ThVIII of Pilbaranella ethelensis; (C, D) male ThVIII of Fortescuenella serenitatis; (E, F) male ThVIII of Anguillanella callawaensis; (G, H) male ThVIII of Muccanella cundalinensis; (I) female ThVIII of Pilbaranella ethelensis; (J) female ThVIII of Fortescuenella serenitatis; (K) female ThVIII of Anguillanella callawaensis; (L) female ThVIII of Muccanella cundalinensis. Scale bar in mm 
WA (fig. 13) but all have endopod and exopod reduced, and the latter curved backwards like Austrobathynellinae, while Bathynellinae and Gallobathynellinae have unfolded and more developed rami. In Pilbaranella the male thoracopod VIII is simplified and reduced; in Fortescuenella it is more complex with a frontal and posterior projection and a well-developed outer lobe; in Muccanella and Anguillanella we have the same structures present in Fortescuenella (frontalposterior projection and outer lobe), but in Muccanella they are reduced while they are welldeveloped in Anguillanella, and both taxa have basipod with crest. Setation on endopod and exopod is the same in all four genera (one short seta on endopod and two setae on exopod).

Female thoracopod VIII (fig. 13) is uniramus like in Austrobathynella patagonica Delamare Deboutteville \& Roland, 1963; it is very simple in Pilbraranella with most of the segments fused; in Fortescuenella and Anguillanella it is formed by: coxopod, basipod and one-segmented ramus, while in Muccanella the ramus is two-segmented. All genera so far described for WA present epipod, contrary to Austrobathynella patagonica.

The pleopod I differs in all taxa by the number of setae, which are all quite elongated in Pilbraranella, Anguillanella and Muccanella, while Fortescuenella presents one very short apical seta. Another character that distinguishes Fortescuenella is the absence of the "special seta X" (Delamare Deboutteville \& Serban, 1973), which is present in the other three genera. All four taxa have four spines on sympod (but different length), two on endopod of uropod and five on furca with distinct ration length.

Specimens from bore YP1o63 show affinity to Anguillanella callawaensis, but also distinctive morphological characters. The only specimen sequenced from bore YRP22 on Yarrie Ridge was a juvenile wholly used for DNA extraction, so no morphological characters are available, but the molecular data place it within the "Anguillanella group" therefore we included it in this genus. Specimens from bores CA0o21 and CAoog9 have slightly different morphology from the rest of
A. callawaensis. Differences could represent intraspecific variation or perhaps the population from these bores is diverging, but not long enough to show clear morphological differences.

Bathynella primaustraliensis (Schminke, 1973), the only bathynellid species described for Australia before 2018 and collected from the Hughes creek in Victoria, differsfrom thenewgenerainmandibleand female thoracopod VIII. A comparison of the male thoracopod VIII (penis) is not possible since the description is based on one female (Schminke, 1973), but we justify the erection of two new genera based on molecular evidence and that bathynellid species and genera of the Pilbara bioregion seem to be restricted to well-defined parts of the catchments where they occur (Perina et al., 2018, 2019).

As Pilbaranella and Fortescuenella, we exclude the new genera from Bathynellinae and Gallobathynellinaesubfamiliesbasedon:numberofteeth on pars molaris and structure of male and female thoracopodVIII, supporting themoleculardata.

The new genera exhibit some common characters with members of the Austrobathynellinae subfamily, but they are quite distinguished from members of Bathynellinae and Gallobathynellinae (table 5). With Austrobathynella Delamare Deboutteville, 1960, Transvaalthynella Serban \& Coineau, 1975 and Transkeithynella Serban \& Coineau, 1975, genera belonging to Austrobathynellinae, Anguillanella and Muccanella present: many teeth on pars molaris of the mandible; female thoracopod VIII reduced to one ramus; male thoracopod VIII with reduced endopod and exopod; and third segment of antennule's endopod very small (short). The paucity of data (only three genera are described based solely on morphological data) prevents us from corroborating the affinity of the new genera Anguillanella and Muccanella to Austrobathynellinae, nevertheless they are more dissimilar from Bathynellinae and Gallobathynellinae and therefore we exclude them. Further morphological and molecular data are needed to outline Bathynellidae subfamilies, resolve taxonomic uncertainties, and systematically organise the taxa discovered in different continents. 


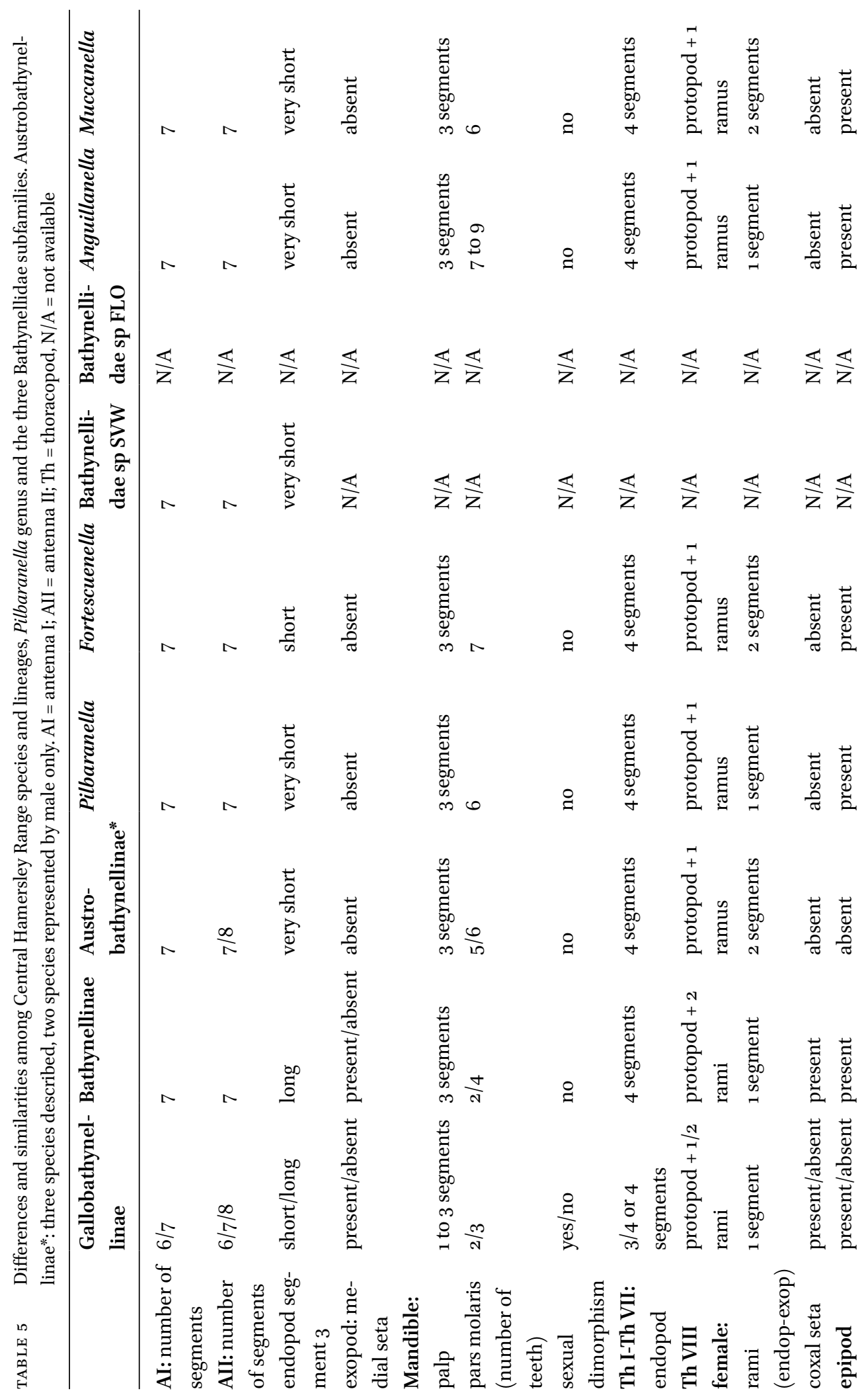




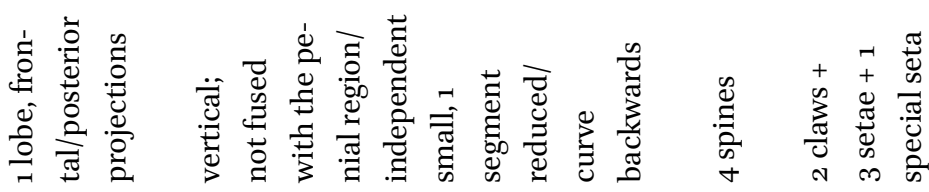

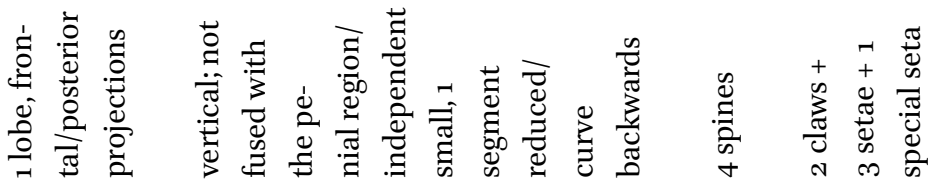

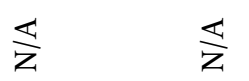

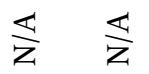

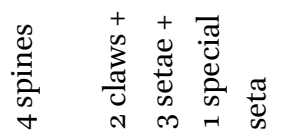

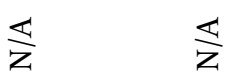

$\overleftrightarrow{\longleftarrow} \quad \frac{1}{z}$

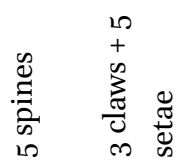

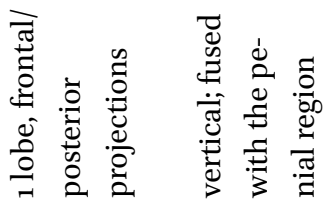

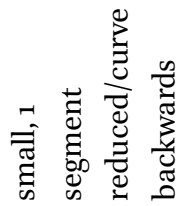

怘

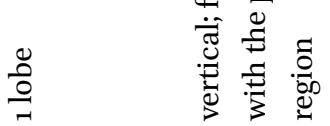

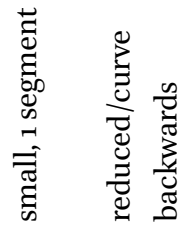

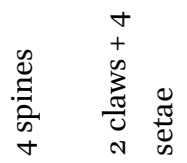

$\stackrel{2}{\circ}$

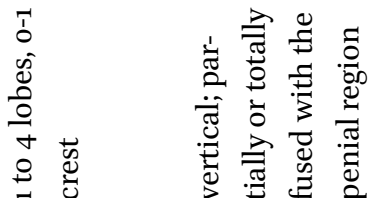

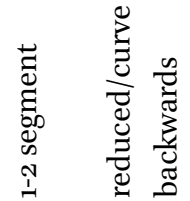

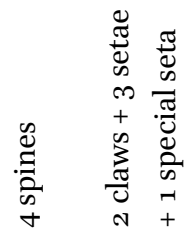

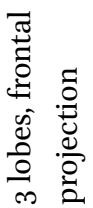

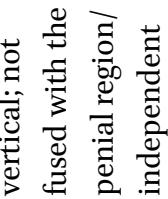

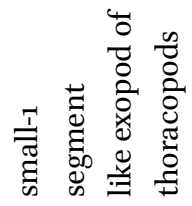

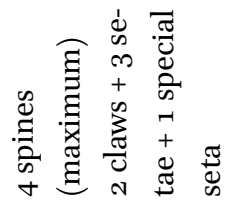

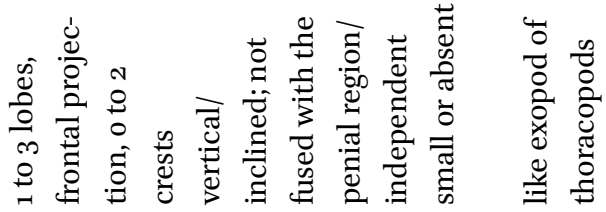

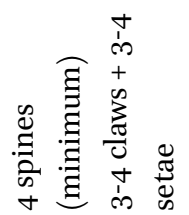

范

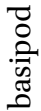

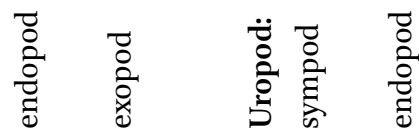

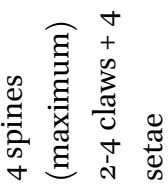




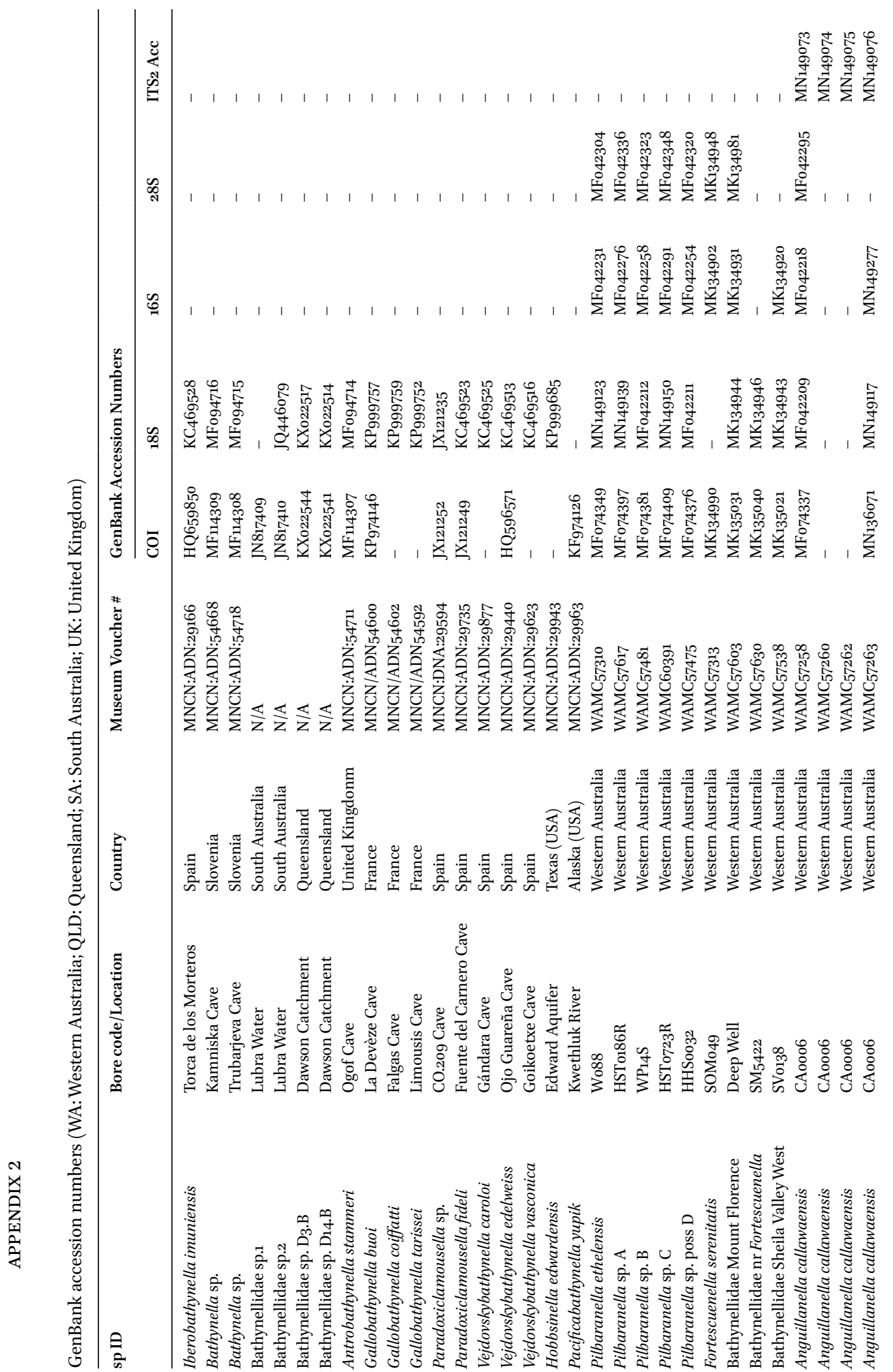




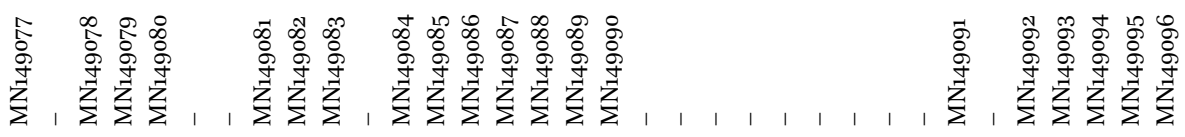

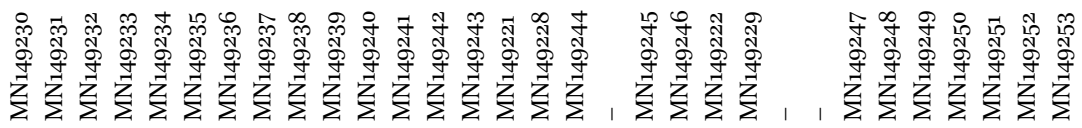

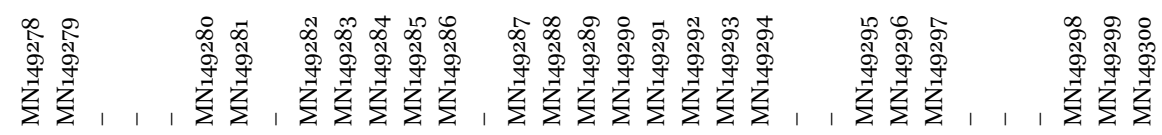

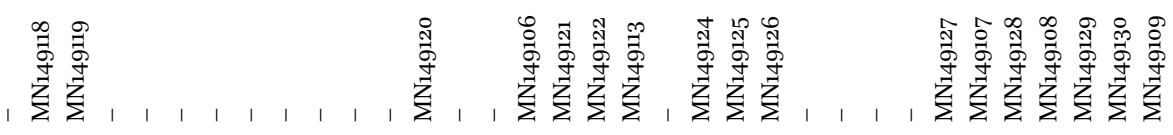

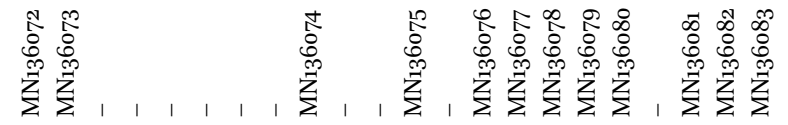

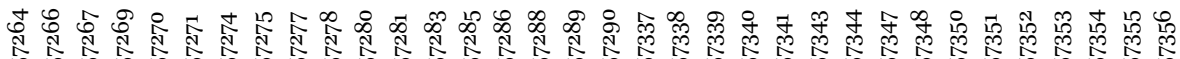

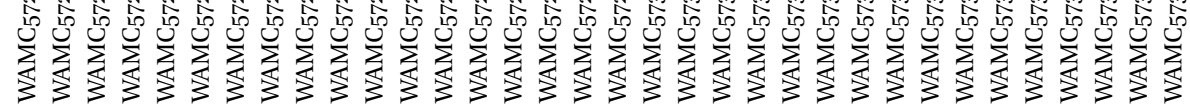

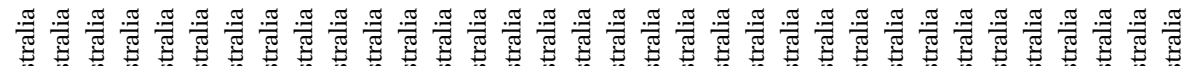

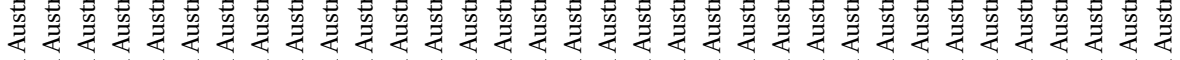

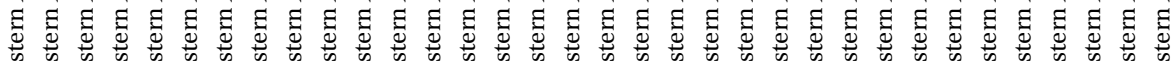

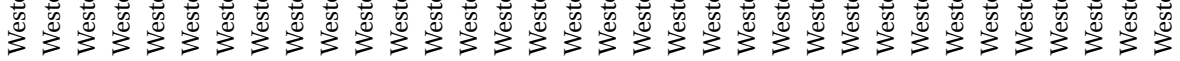

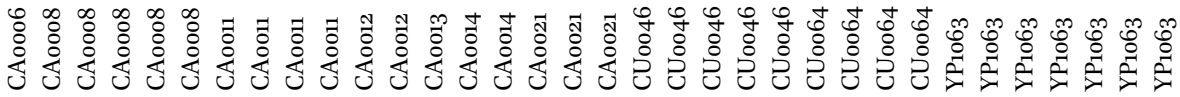

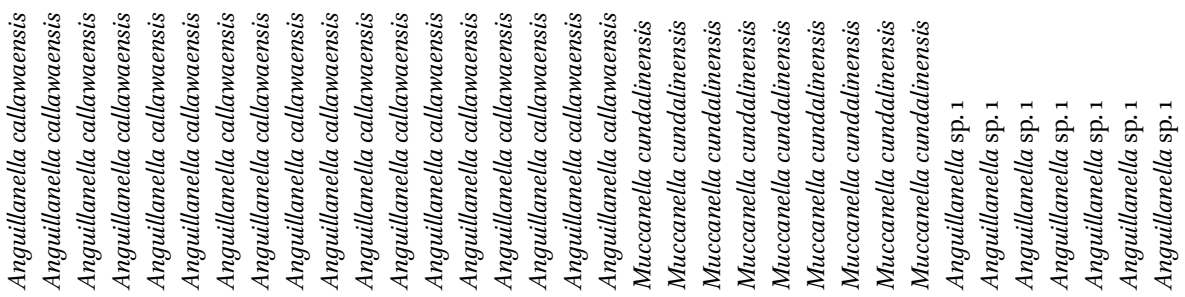




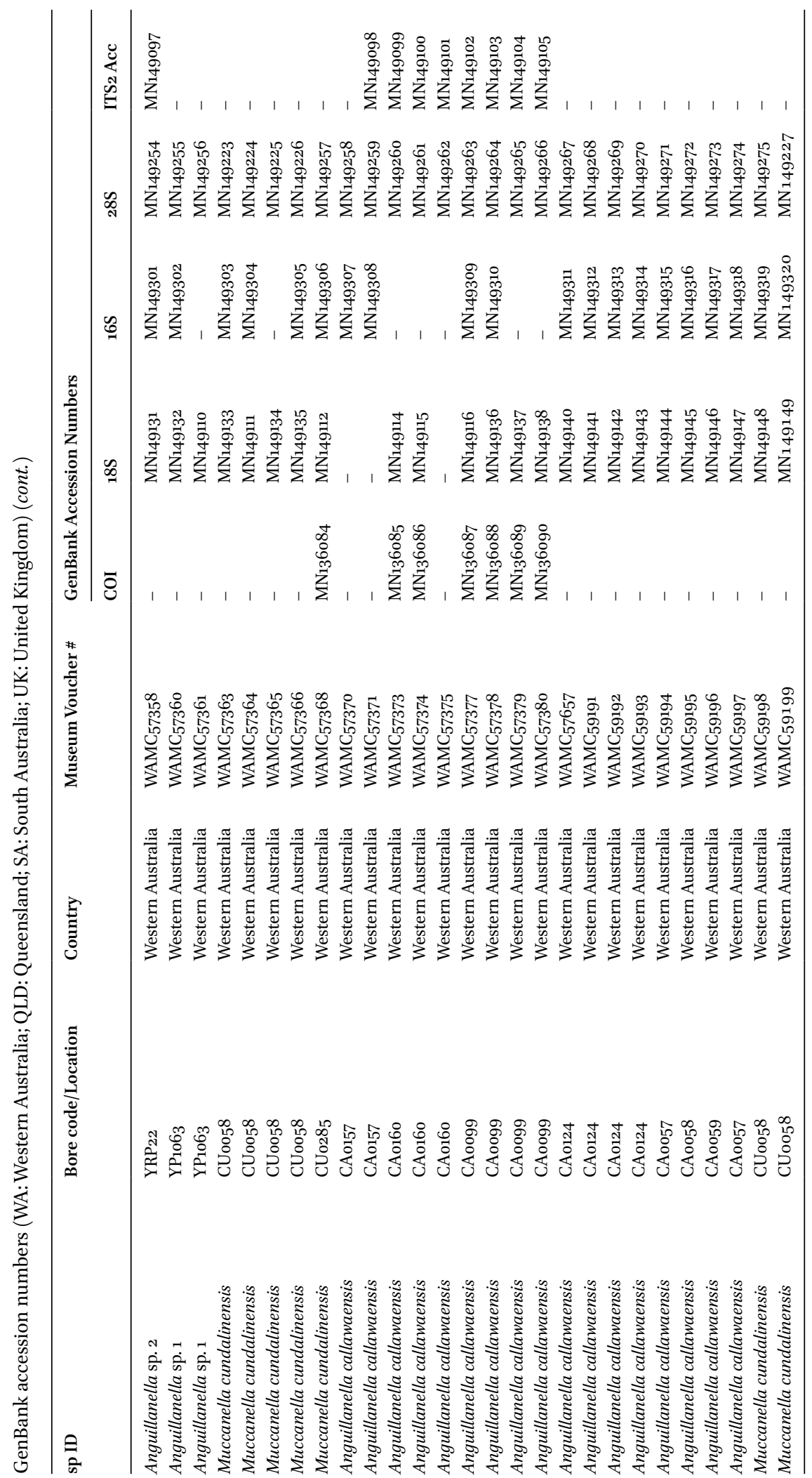




\section{APPENDIX 3}

Bore holes coordinates

\begin{tabular}{|c|c|c|}
\hline Bore & Latitude & Longitude \\
\hline CAooo6 & $20^{\circ} 38^{\prime} 40.02 " S$ & $120^{\circ} 18^{\prime} 22.57^{\prime \prime} \mathrm{E}$ \\
\hline CAooo8 & $20^{\circ} 38^{\prime} 33^{\prime \prime} S$ & $120^{\circ} 18^{\prime} 2^{\prime \prime} \mathrm{E}$ \\
\hline CAoon1 & $20^{\circ} 3^{\prime} 57^{\prime \prime} \mathrm{S}$ & $120^{\circ} 18^{\prime} 17^{\prime \prime} \mathrm{E}$ \\
\hline CAoo12 & $20^{\circ} 39^{\prime} 6^{\prime \prime} S$ & $120^{\circ} 18^{\prime} 23^{\prime \prime} \mathrm{E}$ \\
\hline CAoo13 & $20^{\circ} 39^{\prime} 12.96^{\prime \prime} \mathrm{S}$ & $120^{\circ} 18^{\prime} 14.47^{\prime \prime} \mathrm{E}$ \\
\hline CAoo14 & $20^{\circ} 3^{\prime} 51.10^{\prime \prime S}$ & $120^{\circ} 18^{\prime} 15 \cdot 33^{\prime \prime} \mathrm{E}$ \\
\hline CAoo21 & $20^{\circ} 38^{\prime} 41.92^{\prime \prime} \mathrm{S}$ & $120^{\circ} 17^{\prime} 13.23^{\prime \prime} \mathrm{E}$ \\
\hline CAoo57 & $20^{\circ} 39^{\prime} 37^{\prime \prime S}$ & $120^{\circ} 18^{\prime} 10^{\prime \prime} \mathrm{E}$ \\
\hline CAoog9 & $20^{\circ} 3^{\prime} 40^{\prime \prime} \mathrm{S}$ & $120^{\circ} 17^{\prime} 32^{\prime \prime} \mathrm{E}$ \\
\hline CA0124 & $20^{\circ} 38^{\prime} 54^{\prime \prime} \mathrm{S}$ & $120^{\circ} 17^{\prime} 57^{\prime \prime} \mathrm{E}$ \\
\hline CAo157 & $20^{\circ} 39^{\prime} 25^{\prime \prime} \mathrm{S}$ & $120^{\circ} 17^{\prime} 5^{8^{\prime \prime} \mathrm{E}}$ \\
\hline CAo16o & $20^{\circ} 38^{\prime} 23^{\prime \prime S}$ & $120^{\circ} 18^{\prime} 40^{\prime \prime} \mathrm{E}$ \\
\hline CUoo46 & ${ }^{20}{ }^{\circ} 3^{\prime} 3^{\prime} .46^{\prime \prime} \mathrm{S}$ & $120^{\circ} 09^{\prime} 35 \cdot 42^{\prime \prime} \mathrm{E}$ \\
\hline CUoo58 & $20^{\circ} 32^{\prime} 21.8^{\prime \prime} \mathrm{S}$ & $120^{\circ} 09^{\prime} 12.3^{\prime \prime} \mathrm{E}$ \\
\hline CUoo64 & $20^{\circ} 32^{\prime} 20.61^{\prime \prime} \mathrm{S}$ & $120^{\circ} 09^{\prime} 13.5 " \mathrm{E}$ \\
\hline CU0285 & $20^{\circ} 3^{\prime} 49 \cdot 3^{\prime \prime} \mathrm{S}$ & $120^{\circ} 10^{\prime} 00.98 " \mathrm{E}$ \\
\hline YP1063 & $20^{\circ} 36^{\prime} 11.74^{\prime \prime S}$ & $120^{\circ} 20^{\prime} 23.46^{\prime \prime} \mathrm{E}$ \\
\hline YRP22 & $20^{\circ} 36^{\prime} 32.22^{\prime \prime} \mathrm{S}$ & $120^{\circ} 18^{\prime}{ }_{2} 6.42^{\prime \prime} \mathrm{E}$ \\
\hline
\end{tabular}

